\title{
THE GROUP DYNAMICS THEORY OF EXECUTIVE COMPENSATION
}

\author{
By
}

Michael B. Dorff

\footnotetext{
* Associate Dean for Research and Professor of Law, Southwestern Law School. J.D. Harvard Law School, magna cum laude, 1996. I am deeply grateful for the invaluable comments of Al Calnan, Jim Fischer, Dani Hart, Paul Horwitz, Sung Hui Kim, Carrie Menkel-Meadow, Angela Riley, Lon Sobel, and the participants in the Southwestern Faculty Colloquium. I could not have written this article without the brilliant research assistance of Annabel Blanchard, Elisabeth Duarte, and Bayan Laird. Any remaining errors, of course, are entirely my own.
} 


\section{THE GROUP DYANMICS THEORY OF EXECUTIVE COMPENSATION}

The corporate governance debate has focused recently on executive compensation. While defenders of the status quo assert that CEO compensation - and corporate governance generally -- is efficient, critics contend that boards have been captured by powerful CEOs who demand excessive pay unconditioned on their performance. Both sides argue that the evidence garnered from CEO compensation justifies their positions on legal reform of corporate governance as a whole. Defenders of the status quo argue that the system works well as is, as demonstrated by the enormous success of U.S. corporations. Critics concerned about managerial power propose reforms that will increase board's responsiveness to shareholders, enhancing the board's willingness to act as a check against untrammeled CEO power. In this Article, I take as given that many forms of CEO compensation are less effective than they might be and explore an alternative explanation. Advancing a new, Group Dynamics Theory, I argue that the problems with CEO compensation in public corporations may be caused by the decision-making flaws rooted in group dynamics, particularly groupthink and social cascades. Psychology, rather than economics, may be chiefly to blame. I also propose a very different type of solution, one that targets and improves boards' decision-making processes.

Introduction $\ldots \ldots \ldots \ldots \ldots \ldots \ldots \ldots \ldots \ldots \ldots \ldots \ldots$

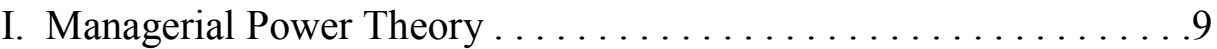

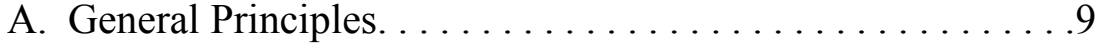

1. Sources of Managerial Power. . . . . . . . . . . 9

2. Limits on Managerial Power - Outrage Costs . . . . 10

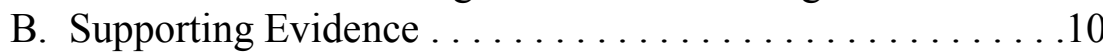

II. Group Dynamics Theory. . . . . . . . . . . . . . . . . . 12

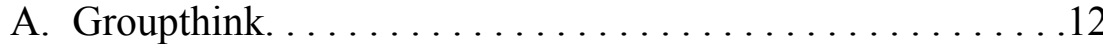

B. Social Cascades .................... 18

III. Accounting for Inefficient Compensation Methods . . . . . . . . . .31

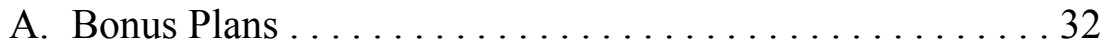

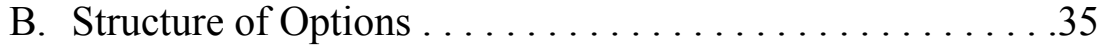

C. Restricted Stock. . . . . . . . . . . . . . . . . . 42

D. Freedom to Unwind Equity Incentives . . . . . . . . .45

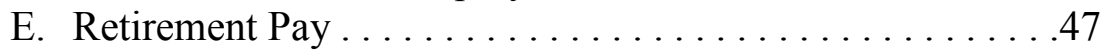


F. Company Loans . . . . . . . . . . . . . . . . . 51

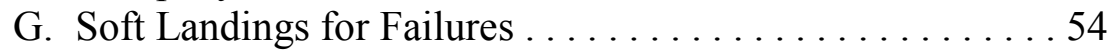

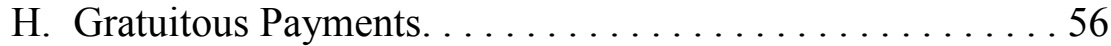

I. Direct Evidence of Power's Impact. . . . . . . . . . . . . .63

IV. Exploring Solutions . . . . . . . . . . . . . . . . .65

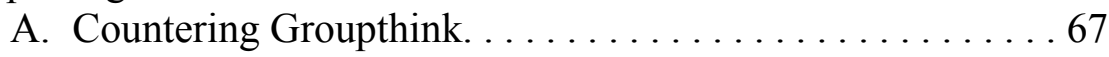

1. Dissent Through Process . . . . . . . . . . . 67

2. Dissent Through Group Composition . . . . . . . . . . 71

B. Dissolving Social Cascades . . . . . . . . . . . 73

Conclusion . . . . . . . . . . . . . . . . . . . . . . . . . . 75

\section{Introduction}

Publicly held corporation. At times, the term has evoked the engine at the heart of our economy, the source of jobs, income, and critical goods and services like food, housing and health care. More recently, the phrase has sometimes possessed a darker connotation, of self-interest run amok, unrestrained executives stealing money from shareholders' and employees' pockets.

Which vision better captures the truth turns in large part on the success of corporate law at instilling the right incentives in corporate officers. The purpose of corporate governance law is to motivate corporate officers - who control the corporation - to act in the interests of corporate shareholders, who own it. ${ }^{1}$ A growing group of legal scholars and commentators in the popular press contends that corporate law is failing in this critical task. ${ }^{2}$ The compensation of chief executive

\footnotetext{
${ }^{1}$ The separation of ownership and control in public corporations was first analyzed systematically by Berle $\&$ Means. See Adolf A. Berle \& Gardiner C. Means, The MODERN CORPORATION AND PRIVATE PROPERTY (1932). Recently, some commentators have begun to question the notion that corporations should pursue shareholders' welfare, but shareholder primacy remains the governing law. See, e.g., Jill Fisch The Role of Shareholder Primacy in Institutional Choice, (October 2004). Queen's Univ. Law \& Economics Research Paper No. 2004-03. Available at SSRN: http://ssrn.com/abstract=704745 or DOI: $10.2139 /$ ssrn.704745.

${ }^{2}$ The leading academic voices for this position are of course Lucian Bebchuk and Jesse Fried, but there are many others. LUCIAN BEBChUK \& JESSE FRIED, PAY WithouT PERFORMANCE (Harvard University Press 2004) (arguing that public company boards are dominated by CEOs and therefore pay their CEOs excessive and poorly structured compensation). See also George P. Baker, et al, Compensation and Incentives: Practice vs. Theory, 43 J FIN 593, 614 (1988) (arguing that directors fail to create proper executive pay arrangements); Linda J. Barris, The Overcompensation Problem: A Collective Approach to Controlling Executive Pay, 68 IND. L.J. 59, 61 (1992)
} 
officers represents the lynchpin of this argument. ${ }^{3}$ Employers pay employees to induce them to work. Smart employers structure their employees' compensation so that the harder and smarter the employees work, the more they are paid. Many scholars now contend that some of the nation's largest employers - publicly held corporations - pay their most important employees regardless of their success or failure. ${ }^{4}$ Public company CEOs, who control inconceivable amounts of other people's

(arguing that executive compensation is excessive); Carl T. Bogus, Excessive Executive Compensation and the Failure of Corporate Democracy, 41BUFF. L. REV. 1, 39 (1993) (applying the law of small group dynamics to the relationship between the board of directors and the chief executive officer); DEREK BOK, THE COST OF TALENT; HOW EXECUTIVES AND PROFESSIONALS ARE PAID AND HOW IT AFFECTS AMERICA 95-114 (1993) (arguing that chief executives are overpaid); Michael B. Dorff, Softening Pharaoh's Heart: Harnessing Altruistic Theory and Behavioral Law and Economics to Rein in Executive Salaries, 51 BUFF. L. REV. 811, 825-26 (2003) (evidence does not support link between executive ability and compensation); Melvin Avon Eisenberg, The Structure Of Corporation Law, 89 COLUM. L. REV. 1461, 1489-93 (1989) (CEO compensation practices do not align interests of managers and shareholders); Tod Perry \& Marc Zenner, CEO Compensation in the 1990s: Shareholder Alignment or Shareholder Expropriation?, 35 WAKE FOREST L REV 123, 145 (2000); Edward D. Rogers, Striking the Wrong Balance: Constituency Statutes and Corporate Governance, 21 PEPP. L. REV. 777, 784 (1994) (explaining that the expense of contesting a board election limits shareholder power to oppose management's nomination); Joel Seligman, A Sheep in Wolf's Clothing: The American Law Institute Principles of Corporate Governance Project, 55 GEO. WASH. L. REV. 325, 331 (1987) (arguing that board nominations by anyone other than management is "virtually impossible"); Kevin J. Murphy, Executive Compensation, (April 1998) Available at SSRN: http://ssrn.com/abstract=163914 or DOI: $10.2139 /$ ssrn.163914 (reviewing the research on executive compensation). The popular press also appears to have adopted this consensus, based on the number of articles decrying excessive CEO compensation. See, e.g., David Bank, Siebel's Plan for Executive Pay Soothes a Powerful Watchdog, THE WALl Street Journal. January 21, 2005; Chad Bray, Pay Expert Calls Disney-Ovitz Pact Unreasonable, The WALl StREeT Journal, October 26, 2004; Rebecca Smith and Jonathan Weil, Ex-Enron Directors Reach Settlement, THE WALL STREET JOURNAL, January 10, 2005; Jeff Madrick, Economic Scene: Where economists stand, or don't stand on the issue of corporate scandals, N.Y. TIMES, October 28, 2004;

Arthur Levitt Jr., Money, Money, Money, The Wall Street Journal, November 22, 2004; David Olive, How do CEOs measure up? Executive compensation is up. A lot. Again. Is there really any value in paying big bucks to the boss? TORONTO STAR, May 15, 2004.

${ }^{3}$ See Michael B. Dorff, Does One Hand Wash the Other? Testing the Managerial Power and Optimal Contracting Theories of Executive Compensation, 30 J. Corp. L. 255, 257 (2005) (describing the importance of executive compensation).

${ }^{4}$ See BeBCHUK \& FRIED, supra note 2, at 121-136 (Noting that executives are frequently paid generous salaries and bonuses regardless of performance levels). 
money, lack the basic financial incentive structures that most factory workers have. Without these incentives, CEOs are likely to pursue their own interests at the shareholders' expense.

Substantial evidence supports this critique. CEO pay has grown by gigantic leaps in the past two decades, far outpacing inflation or the increases in the salaries paid to lower level workers. As a result, while in the early 1980s public company CEOs earned an average of forty-two times what factory workers earned, now they earn some four hundred times as much as factory workers do. ${ }^{5}$ Perhaps even more troublingly, public companies increasingly pay their CEOs in ways that reward them regardless of the CEOs' performance. ${ }^{6}$ Traditional stock options, for example, often become more valuable for reasons completely apart from the company's performance. In 2005, when oil prices climbed dramatically, oil company stock prices rose commensurately. As a result, Ray Irani, the chief executive of Occidental Petroleum, received nearly $\$ 50$ million in compensation that year, the vast majority of which came from stock options. ${ }^{7}$ John Drosdick, Sunoco's chief executive, received almost \$23 million, again mostly in options. ${ }^{8}$ Yet neither company's chief executive caused the spike in oil prices that created their new wealth. Their stories are far from unique. Option holders often benefit greatly from general increases in the stock market due to an expanding economy or lower interest rates, factors having nothing to do with individual performance. How can our most sophisticated employers perform so poorly at the critical task of incentivizing their most important employees?

Critics of the current legal regime argue that the problem lies with the incentives of the board of directors. The board has the sole authority to hire the CEO and negotiate his or her compensation. ${ }^{9}$ The board owes a fiduciary duty to represent the shareholders interests, ${ }^{10}$ but the critics contend that directors' self-interest lies with the CEO, not the

\footnotetext{
${ }^{5}$ See Dorff, supra note 2, at 823.

${ }^{6}$ See BEBCHUK \& FRIED, supra note 2, at 87-185.

${ }^{7}$ See J. Alex Tarquinio, Pay for Oil Chiefs Spiked Like Prices, N.Y. TIMES, April 9, 2006, at BU10.

${ }^{8} I d$.

${ }^{9}$ See, e.g., 8 Del. C. $\$ 141($ a) (the business and affairs of every corporation is managed by the board); Cal. Corp. Code $§ 300$ (a) (same).

${ }^{10}$ Smith v. Van Gorkom, 488 A.2d 858, 872 (Del. 1985).
} 
shareholders. $^{11}$ Directors realize that the CEO exercises enormous influence over the corporation's slate of nominees to the board, and that the corporation's candidates are almost always elected. ${ }^{12}$ Pleasing the CEO is therefore the key to a long directorial tenure. As a result, the negotiation between the board and the CEO over the CEO's compensation is not a fierce contest conducted at arms-length but a cozy connivance between co-conspirators. ${ }^{13}$

This critique - often called "Managerial Power Theory" contrasts with the other major theoretical approach to corporate governance, Optimal Contracting Theory. Optimal Contracting Theory contends that corporate governance - including the process by which boards negotiate CEO compensation - is efficient. ${ }^{14}$ Optimal Contracting scholars point out that public corporations generate vast sums of wealth for their shareholders. If the system was as deeply flawed as critics contend, they say, then how do these critics explain corporations' wild success? Optimal Contracting theorists explain CEOs' rich compensation as evidence, not that boards are captured, but that CEO-level skills and experience are rare and valuable. CEOs

\footnotetext{
${ }^{11}$ See BEBCHUK \& FRIED, supra note 2, at 31-34; see also Bogus, supra note 2, at 37 (arguing the board is under the CEO's complete control); Benjamin E. Hermalin \& Michael S. Weisbach, Endogenously Chosen Boards of Directors and Their Monitoring of the CEO, 88 AM ECON REV 96, 96-97 (1998) (stating that CEOs choose or approve of the board's nominees); Kevin Hallock, Reciprocally Interlocking Boards of Directors and Executive Compensation, 32 J FIN \& QUANT ANAL 331, 332 (1997) (arguing CEOs often can choose new board members).

${ }^{12}$ See BEBCHUK \& FRIED, supra note 2, at 25, 80-86. See also Hermalin \& Weisbach, supra note 11, at 96-97; Hallock, supra note 11, at 332.

${ }^{13}$ See BeBCHUK \& FRIED, supra note 2, at 80-86.

${ }^{14}$ See, e.g., Stephen M. Bainbridge, Why a Board? Group Decisionmaking in Corporate Governance, 55 VAN. L. REV. 1, 3 (2002); Frank H. Easterbrook, Managers' Discretion and Investors' Welfare: Theories and Evidence, 9 DEL. J. CORP. L. 540 (1984); Daniel R. Fischel, The Corporate Governance Movement, 35 VAND. L. REV. 1259 (1982); Sanford J. Grossman \& Oliver D. Hart, An Analysis of the Principal-Agent Problem, 51 ECONOMETRICA 7 (1983); Bengt Holmstrom, Moral Hazard and Observability, 10 BELL J. ECON. 74 (1979); J.A. Mirrlees, The Optimal Structure of Incentives and Authority within an Organization, 7 BELL J. ECON. 105 (1976); Stephen A. Ross, The Economic Theory of Agency: The Principal's Problem, 63 AM. ECON. ReV. 134 (1973); Steven Shavell, Risk Sharing and Incentives in the Principal and Agent Relationship, 10 BELL J. ECON. 55 (1979); Robert Thomas, Is Corporate Executive Compensation Excessive?, in M. Bruce Johnson, ed, THE ATTACK ON CORPORATE AMERICA 276 (McGraw Hill 1978); Nicholas Wolfson, A Critique of Corporate Law, 34 U. MiAmI L. REV. 959 (1980).
} 
command large salaries for the same reason highly successful professional athletes and actors do: their skills are scarce and very productive.

In this Article, I propose a third alternative to explain corporations' observed behavior in compensating their chief executives. I sidetrack the current debate between Managerial Power and Optimal Contracting by assuming that the current pay structures are often inefficient, as Managerial Power advocates contend. I advance a new, Group Dynamics Theory, account of how these inefficiencies may arise. I argue that the problems with CEO compensation in public corporations may be caused by the decision-making flaws rooted in group dynamics. Psychology, rather than economics, may be chiefly to blame.

Behavioral economists and social psychologists have for decades studied a set of behavioral phenomena - termed "groupthink" stemming from membership in a cohesive group, such as a public corporation board of directors. Irving Janis, the leading pioneer in the field, identified seven flaws that often recur in the decision-making processes of such groups. ${ }^{15}$

Other group decision-making defects stem from social cascades. ${ }^{16}$ Social cascades form when many individuals or groups possess little private information regarding a decision, and therefore rely heavily on the actions of others to guide them. ${ }^{17}$ As a result, the early actions of a few individuals - whose power stems not from additional information or wisdom, but simply from temporal primacy - may result in a "cascade" effect, in which large numbers of people repeat the leaders' actions. ${ }^{18}$

These decision-making flaws provide an alternative explanation for many of the executive pay structure weaknesses observed by critics. Directors may use inefficient mechanisms to pay senior executives

\footnotetext{
${ }^{15}$ See IrVIng L. Janis, Groupthink: Psychological Studies of Policy DeCisions AND FIASCOES (2nd ed. 1982 Houghton Mifflin Company).

${ }^{16}$ See Marleen A. O'Connor, The Enron Board: The Perils of Groupthink, 71 U. CIN. L. REV. 1233, 1240 (2003); Cass R. Sunstein, Deliberative Trouble? Why Groups go to Extremes, 110 YALE L. J. 71, 82 (2000).

${ }^{17}$ See Sushil Bikhchandani,, et al., Learning from the Behavior of Others: Conformity, Fads, and Infomrational Cascades, 12 JOURNAL OF ECONOMIC PERSPECTIVES 151, 154 (1998); Sunstein, supra note 16, at 82.

${ }^{18}$ See Abhijit V. Banerjee, A Simple Model of Herd Behavior, 108 QUARTERLY J. ECON. 797, 798 (1992); Bikhchandani , supra note 17, at 154; Sunstein, supra note 16, at 82-84.
} 
because flaws in their decision-making processes interfere with their selection of more efficient compensation devices.

Under Group Dynamics Theory, the role played by CEOs is more ambiguous than under Managerial Power. Executives may actively manipulate the process in an effort to garner greater compensation, taking advantage of the board's vulnerabilities, playing a role similar to that outlined by Managerial Power theorists. ${ }^{19}$ Alternatively, senior officers may be as much victims as beneficiaries of the group's decision flaws, equally unable to perceive the inefficiencies in their own compensation packages.

Most Managerial Power theorists have cited the amount of executive compensation as evidence of a flaw in the compensationsetting system. ${ }^{20}$ They have compared the compensation of U.S. chief executives to that of their European and Japanese counterparts, measured the astonishing growth rate of CEO pay, and pointed out that the ratio of CEO remuneration to workers' salaries has dectupled since the early $1980 \mathrm{~s}^{21}$ This strategy has serious flaws, however, in that it is rooted in the problematic notion that there is some objectively correct - but unidentifiable - pay for CEOs other than that set by the (non-existent) efficient market. Recently, however, Managerial Power theorists have taken a great leap forward with the work of Lucian Bebchuk and Jesse Fried. In their groundbreaking book, Pay Without Performance: The Unfulfilled Promise of Executive Compensation, Bebchuk and Fried ("BF") turn to the structure of executive compensation, rather than the absolute amount, for evidence of managerial power's impact. BF analyze numerous forms of compensation commonly used in chief executive's pay packages - such as stock options - and reveal the seriously flawed incentives such compensation mechanisms produce. ${ }^{22}$ A truly arms-length negotiation should produce efficient payment schemes. $^{23}$ Employers should want pay structures that produce the best possible work from employees. Employees should also want such structures, since the employees' improved efficiency can be exchanged for greater total compensation. If CEOs' pay packages typically are

\footnotetext{
${ }^{19}$ See BEBChUK \& FRIED, supra note 2, at 86.

${ }^{20}$ See, e.g., Barris, supra note 2, at 59-61; Dorff, supra note 3, at 256; Dorff, supra note 2 , at 812,843 ; Perry \& Zenner, supra note 2, at 145.

${ }^{21}$ See Dorff, supra note 2, at 821-25 (citing commentators).

${ }^{22}$ See BEBCHUK \& FRIED, supra note 2, at 121-136.

${ }^{23}$ Id. at 18.
} 
inefficient, then, BF contend that the fault lies at the feet of managerial power over directors. ${ }^{24}$

I argue here that the pay-structure inefficiencies BF catalogue so aptly may have an alternative, or at least an important contributing, cause: Group Dynamics Theory. I also contend that the type of solution advanced by Managerial Power adherents - reducing managers' power over directors - may fail unless supplemented with reforms that also target group dynamics.

I should stress at the outset that I am sympathetic to Managerial Power as well. Indeed, some of my own work supports the thesis. ${ }^{25}$ I agree with Managerial Power theorists that there are deep flaws in the executive compensation system of public corporations, flaws in urgent need of repair. The point I wish to make in this article is that although Managerial Power adherents make a powerful argument, one that often fits the observed data, theirs is not the only explanation for what we see in the marketplace. I posit here an alternative explanation, based on the social psychology of group dynamics, that I argue fits the data equally well. My intent is not to claim that my explanation is correct and theirs mistaken. Rather, I contend that both explanations likely play important roles in producing the current state of affairs, and that we must therefore target the problem with solutions based on both possible explanations.

In Part I of this Article, I briefly summarize Managerial Power's argument, taking BF's work as representative. In Part II, I provide an overview of two insights from behavioral economics and social psychology that together provide an alternative explanation for much of BF's evidence: groupthink and social cascades. Then, in Part III, I highlight the major categories of evidence BF point to in support of the Managerial Power thesis, and provide a Group Dynamics explanation for each. In Part IV, I suggest the need to consider an altogether different type of reform from that proposed by Managerial Power theorists, based on the Group Dynamics Theory interpretation of BF's evidence. I also sketch out what proposals based on Group Dynamics Theory might look like, based on empirical work from social psychology. I conclude with a few thoughts about future research.

\footnotetext{
${ }^{24} I d$. at 61-64, 80-86.

${ }^{25}$ See Dorff, supra note 3 (presenting experimental evidence that executives' power leads to excessive compensation).
} 


\section{Managerial Power Theory}

\section{A. General Principles}

\section{Sources of Managerial Power}

Managerial Power focuses on directors' self-interest in explaining the apparent inefficiencies found in many executive compensation packages and the enormous amount of total executive compensation. ${ }^{26}$ The theory argues that directorships are highly desirable, lucrative, and prestigious positions, which individuals are eager to gain and reluctant to give up. ${ }^{27}$ In 2002 , directors of the largest 200 companies took in an average of $\$ 152,000$ in annual compensation, and many received additional benefits as well. ${ }^{28}$ These rewards are particularly striking when compared to the small investment of time and energy that the position has historically demanded. BF cite a study indicating that independent directors spend roughly 100 hours a year on their board duties. ${ }^{29}$

One might think that directorships' desirability would induce board members to pursue shareholders' interests avidly, to secure reelection. ${ }^{30}$ Critics argue, however, that directors wish to serve management's interests, not shareholders'. ${ }^{31}$ Board elections are rarely contested, outside of the hostile takeover context, so the candidates nominated by the corporation nearly universally secure election. ${ }^{32}$ Directors who wish to remain in office therefore need to please whoever determines the composition of the corporation's slate of nominees. ${ }^{33}$ Scholars contend that in the majority of publicly held corporations, it is the CEO who makes this decision, though often informally. ${ }^{34}$ Directors who wish to retain their positions therefore must garner the CEO's

\footnotetext{
${ }^{26}$ See BEBCHUK \& FRIED, supra note 2, at 23.

${ }^{27} \mathrm{Id}$. at 23 .

${ }^{28} I d$. at 23

${ }^{29} \mathrm{Id}$. at 37

${ }^{30} \mathrm{Id}$. at 25

${ }^{31}$ Id. at $25-27$

${ }^{32} I d$. at 25

${ }^{33}$ See supra note 11.

${ }^{34}$ Although formally, many boards delegate the nomination decision to a committee, the CEO often either sits on the committee or informally consults with its members. See supra note 12.
} 
support for their nomination by the corporation. Since executives are likely to care more about their pay than any other issue facing the board, self-interested board members prioritize satisfying the CEO's desires over setting up an efficient compensation contract. 35

\section{Limits on Managerial Power - Outrage Costs}

What then prevents CEOs from taking all of a corporation's profits as compensation? Why do shareholders end up with any distributions at all?

BF posit that directors do face one constraint that prevents them from handing over the corporate treasury to the management team. If directors are too obviously overpaying the CEO, the financial press and institutional shareholders will notice, and advocate for change, whether by amending the corporation's bylaws to impose restrictions on compensation, or by voting in a new slate of directors, or advocating for broader changes in corporate governance law. ${ }^{36}$ These "outrage costs" cause directors, in league with the management team, to conceal the excessive compensation as best they can, often by making it seem based on the CEO's performance. ${ }^{37}$ In fact, though, very little of the CEO's compensation is based on his or her own success. ${ }^{38}$

\section{B. Supporting Evidence}

BF's central - eminently reasonable, in my view - thesis is that a truly independent board would design a compensation package that maximized the CEO's incentive to perform, at the lowest cost possible. ${ }^{39}$ BF enumerate over a dozen examples of features executive compensation plans commonly share that they argue would not exist (at least not commonly) if boards negotiated efficient contracts with executives at arm's length. ${ }^{40}$ These forms of compensation, BF argue, camouflage excessive compensation. They appear to depend on the

\footnotetext{
${ }^{35}$ See BEBCHUK \& FRIED, supra note 2, at 80-86.

${ }^{36} I d$. at 67.

${ }^{37} \mathrm{Id}$.

${ }^{38} \mathrm{Id}$. at $121-185$.

${ }^{39} \mathrm{Id}$. at 2.

${ }^{40} I d$. at 87-189 (discussing "anomalies" in executive pay that would not exist if compensation were negotiated at arm's length).
} 
CEO's success, but actually reward CEOs regardless of how well they perform their jobs. ${ }^{41}$

BF's most prominent example is the conventional stock option. Stock options give the holder the right to buy a set number of shares of the company's stock at a predetermined "strike price." The strike price is almost always set at the stock's market price on the day the option is granted. Stock options appear to reward CEOs only when they do their jobs well, as measured by an increase in the company's stock price. When option holders exercise their stock options, they receive the agreed number of shares in exchange for the strike price. If the stock price has risen higher than the strike price, the holder profits to the extent of the difference. If, on the other hand, the stock price remains at the same level or has declined, the option holders cannot make money by exercising the stock options. ${ }^{42}$ Stock options therefore appear to reward CEOs only when they have succeeded as measured by the metric that arguably matters most to shareholders: the value of their stock.

$\mathrm{BF}$ deconstruct the perception that traditional stock options reward CEOs for their work. They point out that traditional options increase in value for reasons having nothing to do with any action taken by the CEO to improve the company's business. A decrease in interest rates, for example, or high economic growth may cause the stock market as a whole to rise. The resulting increase in the value of the CEO's stock options represents a windfall to the $\mathrm{CEO}$, one that could easily be avoided. A board driven by shareholders' interests would presumably prefer to reward the CEO only for improvements in the company's performance relative to its competitors. Such a board could easily achieve this goal by indexing the options' strike price to an industry benchmark. Indexed options would filter out windfall gains and reward CEOs only for their success in running the company.

$\mathrm{BF}$ argue that the near total absence of indexed options from CEO compensation plans provides strong evidence that boards are focused on rewarding their CEOs, not motivating them to perform. ${ }^{43}$ Their arguments for other forms of compensation follow essentially the same structure: since a given form of compensation is not as strictly performance related as it could be, it must be the product of CEOs'

\footnotetext{
${ }^{41}$ Id. at $121-185$.

${ }^{42}$ See Iman Anabtawi, Explaining Pay Without Performance: The Tournament Alternative, 54 EMORY L. J. 1557, 1567 (2005) (explaining stock options).

${ }^{43}$ See BEBCHUK \& FRIED, supra note 2, at 137-185.
} 
power over their directors. In Part III, below, I will set out some of these arguments in more detail. First, though, I will describe my Group Dynamics Theory, and outline its alternative explanation for the prevalence of inefficient compensation mechanisms.

\section{Group Dynamics Theory}

Two phenomena of group dynamics offer an alternative explanation for the pay structure inefficiencies $\mathrm{BF}$ have analyzed: groupthink and social cascades. In this section, I will briefly describe each of these characteristics of group decision-making and then explain how they may account for certain troubling aspects of the executive compensation system.

\section{A. Groupthink}

Groupthink consists of a set of decision-making flaws characteristic of cohesive groups which strive for unanimity. ${ }^{44}$ To illustrate how groupthink works, let us begin with a hypothetical. A group of disaffected third year law students decides to run as a slate to head the student government. They all attended the same college and all agree that college was much more fun than law school. They also all agree on the solution: more parties, the kind they enjoyed so much in college. The group runs on that platform and wins by a narrow margin in an election with a very small turnout. They explain to themselves that the low turnout is a further symptom of the same problem. Once they build a rich social life on campus, the student body will develop into a more energized community that cares more about the school.

They plan their first party for the following Saturday night. The party is exactly like the ones they threw in college, with limitless beer, plenty of junk food, and a very loud band. Although fewer students attend than they had hoped, they consider the event largely a success, and assure each other that the resulting good word-of-mouth will lead to greater attendance at the next one. Two weeks later, they throw another party. Fewer people show up. Although a few students tell them they are too old for keggers now, the clique blames the result on a midterm

\footnotetext{
${ }^{44}$ See JANIS, supra note 15, at 9-10; Daniel P. Forbes \& Frances J. Milliken, Cognition and Corporate Governance: Understanding Boards of Directors as Strategic DecisionMaking Groups, 24 ACAD. OF MGMT. REV. 489, 496-97 (1999).
} 
being held that Monday in a large class. At the third party, the crowd is even thinner.

Now the group faces some difficulty. They had counted on admission fees to fund the festivities. They broke even on the first party, but lost so much money on the subsequent events that they lack the funds for any more. They decide that poor publicity was to blame for their most recent failure, and decide to spend money budgeted for flying out the graduation speaker on one more bash. They are certain that this time, the students will come. Then they can achieve their original goals and make enough money to continue to fund future events (not to mention repay the money borrowed from the graduation budget). Unfortunately, this party too is a bust.

How could the students have made the same mistake over and over again? Why did they fail to learn from the clear evidence that their desires were not shared by most of their colleagues?

The answer may lie in a phenomenon of group dynamics called groupthink. The researcher most closely associated with groupthink theory is Yale social psychologist Irving Janis. Janis identified seven characteristics of groups that together cause serious group decisionmaking flaws or "groupthink." 45 These include his observations that cohesive groups generally consider only a limited range of options, seldom consider the goals to be met by the decision, and rarely delve beyond the obvious disadvantages of the choice initially favored by the majority of the group. ${ }^{46}$ They tend to avoid seriously considering options initially opposed by the majority. ${ }^{47}$ Cohesive groups often forego the opportunity to consult with experts from outside the group who might provide data or opinions that undermine the favored option. ${ }^{48}$ Even when confronted with contrary data, cohesive groups tend to ignore information that argues against the favored policy, and to highlight information that supports that policy. ${ }^{49}$ Finally, cohesive groups neglect to form contingency plans to deal with foreseeable obstacles to success. ${ }^{50}$

Cohesion as a whole is often considered a desirable group characteristic. Groups that lack cohesion may expend too much energy

\footnotetext{
${ }^{45}$ See JANIS, supra note 15 , at 9-10.

${ }^{46} I d$.

${ }^{47} I d$.

${ }^{48} I d$.

${ }^{49} I d$.

${ }^{50} \mathrm{Id}$.
} 
mediating conflicts to achieve their goals. As Donald Langevoort has written, "[A] plausible interpretation of board cohesion is that it rests on a sound intuition: that the most productive boards are the ones where insiders and outsiders work cooperatively, not at odds with each other." Langevoort argues that lack of cohesion reduces trust, impedes communication, and complicates debate. ${ }^{52}$ Similarly, Stephen Bainbridge trumpets the positive value of group cohesion. ${ }^{53}$ While acknowledging the dangers of groupthink, Bainbridge contends that directors' cohesiveness can lead to the development of positive social norms that enhance the boards' ability to monitor the corporation. ${ }^{54}$

While some cohesion is useful, too much cohesion leads to groupthink. ${ }^{55}$ As with the student government clique, excessive cohesion, combined with a lack of cognitive conflict, can produce poor decision-making. ${ }^{56}$ The students began with a reasonable notion, that their colleagues would enjoy large, college-style parties. Unfortunately, the students chose only their close friends for their slate, people who socialized mostly with one another and who all enjoyed the same activities. As a result, there was no one in the clique who began the process thinking that the other students at the school might have different preferences. Had contrasting ideas been represented, they might have sparked an initial debate that left the students open to the possibility that they might have misjudged their classmates' desires. Instead, the group became mutually reinforcing, with each member reassuring the others that large parties were universally appealing. Even as the countervailing evidence mounted, with each party less successful than the one before, the group proved unable to consider a view that conflicted with their strong consensus. They found it impossible to conceive that anyone would feel differently, that the group's fundamental assumptions could be misguided.

\footnotetext{
${ }^{51}$ Donald C. Langevoort, The Human Nature of Corporate Boards: Law, Norms, and the Unintended Consequences of Independence and Accountability, 89 GEO. L. J. 797, 799 (2001).

${ }^{52} \mathrm{Id}$. at 800 .

${ }^{53}$ See Bainbridge, supra note 14 , at 38.

${ }^{54} \mathrm{Id}$.

55 See JANIS, supra note 15, at 12-13.

${ }^{56}$ See Forbes \& Milliken, supra note 44, at 496-97.
} 
The most famous experiment demonstrating the power of social conformity was conducted by Samuel Asch. ${ }^{57}$ Asch presented subjects with three lines and asked them which best matched a line on a white card. ${ }^{58}$ The task was not difficult; $99 \%$ of the subjects answered the question correctly in the absence of experimental manipulations. ${ }^{59}$ Asch asked the same question, however, of solitary subjects in a group of experimental confederates. ${ }^{60}$ Asch's plants were asked the question first, and each chose the same, incorrect, answer. ${ }^{61}$ Faced with a strong social consensus that contradicted their private opinions, over $70 \%$ of the subjects went along with the group at least once. ${ }^{62}$

Groupthink seems likely to develop on many corporate boards. ${ }^{63}$ Janis argued that both friendship and prestige tend to promote group cohesiveness. ${ }^{64}$ As he wrote, "Concurrence-seeking tendencies probably are stronger when high cohesiveness is based primarily on the rewards of being in a pleasant 'clubby' atmosphere or of gaining prestige from being a member of an elite group than when it is based primarily on the opportunity to function competently on work tasks with effective coworkers." 65 BF and others have pointed out that directors are often selected on the basis of personal friendships and networking. ${ }^{66}$ Also,

\footnotetext{
${ }^{57}$ See Solomon E. Asch, Social Psychology 450-59 (Prentice-Hall Publishers 1952). See also Asch, Opinions and Social Pressure, in READINGS ABOUT THE SOCIAL ANIMAL 13 (Elliot Aronson ed., 1995); Asch, Studies of Independence and Conformity, 70 Psych.. MONOGRAPHS: GEN. AND APPliEd 1 (1956).

${ }^{58}$ See AsCH, supra SocIAL PSYCHOLOGY note 57, at 450-59; See also Sunstein, supra note 16, at 79; Sung Hui Kim, The Banality of Fraud: Re-Situating the Inside Counsel as Gatekeeper, 74 FORDHAM L. REV. 983, 1019-21 (2005).

${ }^{59}$ See supra note 58.

${ }^{60} \mathrm{Id}$.

${ }^{61} \mathrm{Id}$.

${ }^{62} \mathrm{Id}$.

${ }^{63}$ See Bainbridge, supra note 14, at 32; Langevoort, supra note 51, at 810-11 (boards naturally trend towards collegiality and hence groupthink). See also Marleen A. O'Connor, The Enron Board: The Perils of Groupthink, 71 U. CIN. L. REV. 1233, 126169 (2003) (arguing the Enron board suffered from groupthink).

${ }^{64}$ See JANIS, supra note 15, at 247.

${ }^{65} \mathrm{Id}$.

${ }^{66}$ See BEBCHUK \& FRIED, supra note 2, at 31, 81. See also Barry Baysinger \& Robert E. Hoskisson, The Composition of Boards of Directors and Strategic Control: Effects on Corporate Strategy, 15 ACAD. MGMT. REV. 72, $72-73$ (1990); Charles M. Elson, Executive Compensation-A Board-Based Solution, 34 B.C.L.REV. 937, 975-76 (1993); O'Connor, supra note 63, at 1249. See also Bainbridge, supra note 14, at 37-38 (endorsing boards generally but with the caveat that a CEO's personal ties with board
} 
directorships of public corporations are highly prestigious, which contributes to a sense of group competence that may inhibit directors' willingness to consult outside opinions. ${ }^{67}$

Janis also contended that a group's lack of diversity in training and background contributes to groupthink. ${ }^{68}$ Public company boards overwhelmingly consist of white, middle-aged men from privileged backgrounds who have spent their careers working for large corporations. ${ }^{69}$ Although the board's homogeneity contributes to the board's effectiveness by facilitating communication, lack of diversity also reduces dissent, contributing to groupthink. ${ }^{70}$ Not surprisingly, then, many scholars have argued that corporate boards may be particularly susceptible to groupthink. ${ }^{71}$

Groupthink may account for many of the inefficiencies in executive compensation BF have observed. Organizations suffering from groupthink rarely consider more than a few options when faced with a decision, generally fail to examine the goals they seek to meet with the decision, and seldom consider disadvantages beyond the obvious of the plan initially favored by the group. ${ }^{72}$ Corporate boards' failure to choose efficient modes of compensation may therefore result from a paucity of considered options and a failure to examine possibilities closely and in relation to the boards' goals.

The heart of BF's argument is that many - perhaps most - of the forms of compensation commonly awarded to chief executives of publicly held corporations are inefficient; corporations could purchase more incentive power with less money by using other forms or changing some of the terms of the traditional compensation structures. ${ }^{73}$ Their

members may lead to an exploitative relationship).

${ }^{67}$ See JANIS, supra note 15, at 247. See also JAY W. LORSCH AND ELIZABETH M. MACIVER, PAWNS OR POTENTATES?: THE REALITY OF AMERICA'S CORPORATE BOARDS 64 (1989).

${ }^{68}$ See JANIS, supra note 15 , at 250.

${ }^{69}$ See KoRn/FERRY InTERNATIONAL, ANNUAL BOARD OF DiRECTORS STUDY 10 (2003) (finding that in $2002,83 \%$ of boards included a CEO or COO of another company, while only 44\% included even one African American board member and only 17\% included at least one Latino board member).

${ }^{70}$ See JANIS, supra note 15, at 250. See also Bainbridge, supra note 14, at 32.

${ }^{71}$ See Bainbridge, supra note 14, at 32; James Fanto, Whistleblowing and the Public Director: Countering Corporate Inner Circles, 83 OR. L. REV. 435, 462-466 (2004); Forbes \& Millken, supra note 44, at 496; O’Connor, supra note 63, at 1239.

${ }^{72}$ See JANIS, supra note 15, at 9-10.

73 BEBCHUK \& FRIED, supra note 2, at 121-122, 136, 138-143. 
critiques of the various modes of compensation, though, are often complex and subtle. They are not arguments that will automatically occur to boards, and are not points that boards will see as obviously correct, even if someone raises them. As I will discuss in some detail below, BF's arguments are sharply contested, giving plenty of cover to CEOs to support maintaining the favorable status quo. ${ }^{74}$

Even though BF's arguments might prove convincing to a board that seriously considered them, groupthink boards are unlikely to do so in the face of the CEO's opposition. Groups subject to groupthink are unusually likely to follow their leader, because they perceive the leader as best embodying the group's values. ${ }^{75}$ Also, group members tend to vote with their leader's views in order to reduce the stress generated by some external threat or internal dilemma. ${ }^{76}$ Stress temporarily lowers self-esteem, but joining the consensus created by a respected leader can reduce this stress and restore self-confidence. ${ }^{77}$ Groupthink boards are therefore far more likely to vote with their leader, the CEO, and to perceive the CEO's views to be those of the board's majority.

The CEO is unlikely to favor a close examination of the traditional compensation structures. As BF point out, it is against the CEO's interest to have pay tied closely to performance. ${ }^{78}$ CEOs would understandably prefer risk-free compensation. ${ }^{79}$ The board is therefore unlikely to seriously consider reform proposals that would impose significantly greater risk on the CEO, the group's leader. The CEO plays a similar role under both groupthink analysis and Managerial Power, acting in his or her own self-interest to self-consciously manipulate the board. $^{80}$

One critique BF might raise to this argument is that even if boards have historically missed the inefficiencies of the traditional pay packages, BF have now brought those flaws to light. Even boards acting

\footnotetext{
${ }^{74} I d$.

${ }^{75}$ See Fanto, supra note 71, at 463-64. See also John M. Levine \& Lauren B. Resnick, Social Foundations of Cognition, 44 ANN. REV. PSYCH. 585, 601 (1993) (pointing out that groupthink is particularly present in cohesive groups with strong, directing leaders).

${ }^{76}$ See JANIS, supra note 15 , at 255-56.

${ }^{77} \mathrm{Id}$.

${ }^{78}$ See BEBCHUK \& FRIED, supra note 2, at 9-10.

${ }^{79} \mathrm{Id}$. at 17.

${ }^{80} \mathrm{Id}$. at 61-64.
} 
through the miasma of groupthink ought now to understand the problems with these methods and act to correct them.

But groupthink is too robust to be dispelled by a single academic book, even one as enormously influential as Pay Without Performance. Cohesive groups often avoid contact with experts from outside the group who might provide data or opinions that undermine the favored option. ${ }^{81}$ Even when confronted with contrary data, cohesive groups tend to ignore information that argues against the favored policy and to highlight information that supports that policy. ${ }^{82}$ In addition, the Asch experiments demonstrate that social pressures can induce individuals to make decisions they know are objectively incorrect. ${ }^{83}$

Nevertheless, there are limits to the power of groupthink to produce inefficient outcomes. Because groupthink depends on the power of consensus, and not self-interest, the phenomenon should have more difficulty producing decisions that are obviously wrong. The Asch experiments asked questions with obvious correct answers. Yet in those experiments, while seventy percent of the subjects who answered a series of questions conformed to group pressure at least once, subjects resisted the group's influence and answered correctly nearly two-thirds of the time. ${ }^{84}$ Although Asch's experiments demonstrate the power of groupthink to persuade people to vote even for clearly wrong answers, groupthink's power should be at its apex when the group faces questions to which there is no clear, objectively correct answer. As I will argue below in Part III, the inefficiencies BF identify generally fall into this category. ${ }^{85}$ First, though, I will discuss a second aspect of group dynamics, social cascades.

\section{B. Social Cascades}

A hypothetical may again prove useful to illustrate social cascades. Imagine a law student on the first day of law school. Suppose the professor begins class by asking whether the first case was correctly decided. Instead of calling on a single student for the answer, however, the professor moves along the rows, asking each of the one hundred

\footnotetext{
${ }^{81}$ See JANIS, supra note 15 , at 9-10.

${ }^{82} \mathrm{Id}$.

${ }^{83}$ See supra, note 62.

${ }^{84} \mathrm{Id}$.

${ }^{85}$ See infra Part III.
} 
students to respond "yes" or "no." The students who respond "yes" are asked to move to the right front corner of the room; those who answer "no" move to the front left.

Our student sits in the second row. The first three students all answer "yes," and move to the right corner. The fourth answers "no" and moves to the left, but then the next five students in a row answer "yes."

Remember, this is the student's first day. Although she read the case the night before and disagreed with the court's holding (putting her in the "no" camp), she lacks confidence in her nascent legal judgment. Perhaps the other students, who have almost all answered "yes," have a better understanding of the case than she has. Also, if she is going to answer incorrectly, she would prefer to be part of a large group. Being one of only a handful of students to give the wrong answer would be highly embarrassing, but there is little shame if most of the class was fooled. On balance, since she has so little information of her own, she decides to go with the majority and answer "yes."

Our law student has just demonstrated the power of social cascades. When people make a decision sequentially, and that decision is public, at some point in the chain, individuals may begin to ignore their private information in favor of the crowd's views. ${ }^{86}$ This response may be a rational calculation that the crowd has more information than any single individual, as in our law student's perception that the nearly unanimous judgment of her peers probably represented a more informed answer than her own opinion. ${ }^{87}$

Alternatively, it may represent an attempt to preserve reputation, at the expense of making an incorrect decision. ${ }^{88}$ Our law student, for example, answered opposite to her private judgment in part out of concern that she risked consequences to her reputation if she answered differently. Or imagine a teenager who, while in a music store with a group of friends, purchases a popular Gwen Stefani CD rather than the less hip, but to her more interesting, Postal Service album. Although she prefers The Postal Service, she fears her friends will mock (or even shun) her if she buys music that is out of the mainstream. Reputationinduced cascades in this way share many of the characteristics of

\footnotetext{
${ }^{86}$ See supra, note 17.

${ }^{87}$ See Banerjee, supra note 18, at 798; Bikhchandani, supra note 17, at 154.

${ }^{88}$ See Sunstein, supra note 16 , at 78.
} 
groupthink, but cascades caused by lack of private information may respond quite differently.

The behavior of individuals involved in social cascades may be rational. ${ }^{89}$ Particularly when the actor has little other information, following the lead of the crowd, even a crowd of strangers, may represent the best strategy. If each person in the group makes an independent decision, based on his or her own information and ignoring those who preceded him or her, then the crowd's decision should contain a great deal of information, the aggregation of each individual's private knowledge. Social cascades arise, however, when most people adopt the "follow the crowd" strategy rather than making an independent decision. ${ }^{90}$ When most individuals ignore their own information in favor of following the majority, the group's decision contains only the information of the first few decision-makers. If these pioneers happen all to make the same, wrong selection, the bulk of the group may fall in line even if the decision contradicts their own private information. ${ }^{91}$

A famous classroom experiment designed by economists Lisa Anderson and Charles Holt should serve to illustrate the principle. ${ }^{92}$ Anderson and Holt placed three balls in each of two urns, A and B. In urn A, they placed two light balls and one dark ball; in urn B they placed two dark balls and one light ball. ${ }^{93}$ They then flipped a coin to determine which urn would be chosen, and poured the balls of the chosen urn into a third urn or cup. ${ }^{94}$ Students were then invited up in random order to draw a ball from the cup, replace it, and then guess which urn had been chosen. ${ }^{95}$ The student's decision was publicized to the rest of the class, but the signal (the color of the ball drawn) remained private. ${ }^{96}$

A student who draws a light ball from the cup should guess urn A, since the probability is two to one that urn A was chosen. ${ }^{97}$

\footnotetext{
${ }^{89}$ See supra, note 87.

${ }^{90}$ See Bikhchandani, supra note 17 , at 154.

${ }^{91} \mathrm{Id}$. at 154-55.

92 See Lisa R. Anderson \& Charles A. Holt, Classroom Games: Information Cascades, 10 J. ECON. PERSP. 187 (1996) (describing game); See also Lisa R. Anderson \& Charles A. Holt, Information Cascades in the Laboratory, 87 AM. ECON. REV. 847 (1997) (describing experimental results).

${ }_{93}^{3}$ See Anderson \& Holt (1997), supra note 92, at 849.

${ }^{94}$ See Anderson \& Holt (1996), supra note 92, at 189.

${ }^{95}$ See Anderson \& Holt (1997), supra note 92, at 849.

${ }^{96} \mathrm{Id}$.

${ }^{97}$ Since urn A has two light balls, and urn B only one, the odds are two to one that any light ball chosen came from urn A.
} 
Conversely, a student who draws a dark ball from the cup should guess urn B, since the same odds favor that urn B was chosen. In both cases, the student should be correct two-thirds of the time. ${ }^{98}$ So far, the game appears quite straight-forward.

The game becomes more interesting, however, once more students begin to play. Suppose that urn A is selected in the coin toss. If the first student draws a light ball, and guesses urn A, and the second student also draws a light ball, the second student should also guess urn A, since the publicly available information (that the previous student had drawn a light ball) matches the student's private information (that this student also drew a light ball). But what if both the first and second students draw dark balls? Both should select urn B: the first student because a dark ball has a two to one chance of coming from urn $\mathrm{B}$, and the second student both for that reason and because the first student's choice of urn B indicates that he also drew a dark ball. Even if the third student then draws a light ball, she should choose urn B. Although her private information (the light ball) indicates that urn A was more likely the winner of the coin toss, the two previous students' selections suggest that they both drew dark balls. Since dark balls were drawn twice, and a light ball only once, the third student should guess urn B. ${ }^{99}$

This is how cascades begin. ${ }^{100}$ From this point on, no matter what color ball each student draws, he or she should guess urn B. The publicly available information (that every student before has chosen urn $\mathrm{B}$ and therefore presumably drawn a dark ball) overwhelms the privately available information (that this particular student may have drawn a light ball). Anderson and Holt observed in their experiment that cascades began in $75 \%$ of the games in which they were possible, that is, when the first two students both drew the same color balls. ${ }^{101}$

Social cascades may help explain some of the executive compensation phenomena BF noted. For a social cascade to begin, the decision-makers must not possess very much private information. ${ }^{102}$ Most board members probably fulfill this criterion when faced with compensation decisions. Board members are rarely experts on executive compensation. Public company directors are generally either CEOs of

\footnotetext{
${ }^{98}$ See Anderson \& Holt (1997), supra note 92, at 849.

${ }^{99} \mathrm{Id}$. at $849-50$.

${ }^{100} \mathrm{Id}$. at 850.

${ }^{101} \mathrm{Id}$. at 851-52.

${ }^{102}$ See Sunstein, supra note 16, at 76.
} 
other public companies or firm lawyers, investment bankers, former politicians, or prominent academics. ${ }^{103}$ Most of these groups cannot be expected to possess much expertise on this subject. Lawyers who work in law firms are accustomed to very simple compensation structures in their own work. Law firms generally charge an hourly rate for their work, or sometimes a percentage of the recovery in litigation. Investment bankers are generally paid with a straight cash fee for advisory work, or a percentage of the deal, whether it be a securities offering, or the sale or acquisition of a business. Politicians and academics are nearly universally compensated with a simple salary and benefit structure.

Of these groups then, only CEOs are at all likely to have a detailed comprehension of the incentive effect of such immensely complicated pay packages. CEOs presumably understand the content of their own pay packages, and have a sense of the effect of the various components on their own incentive to act in shareholders' interests. But this intuition comes only from CEOs' own reactions to such incentives and is not based on a scientific inquiry into the actual impact of different compensation methodologies.

Worse, CEOs functioning as directors of another corporation can be expected to experience cognitive dissonance in regard to payment structures that they themselves enjoy. ${ }^{104}$ Payment types that are inefficient from shareholders' perspectives - because they fail to motivate the CEO to act on their behalf - are correspondingly advantageous to CEOs, who are thereby left free to pursue their own interests. CEOs who benefit from inefficient types of compensation (from the shareholders' perspective) are therefore committed to the notion that such structures are beneficial to the corporation and its shareholders. Admitting to themselves or their colleagues on the board that a form of compensation is inefficient would require them to confront the knowledge that they have accepted such payments themselves, at the expense of their shareholders. Faced with such cognitive dissonance, CEOs can be expected to resist strongly any questioning of common compensation methods' efficacy.

\footnotetext{
${ }^{103}$ See Dorff, supra note 3, at 265.

${ }^{104}$ Cognitive dissonance refers to individuals' discomfort when their actions contradict their beliefs. People tend to act to reduce their cognitive dissonance, by changing their beliefs to justify their behavior. See generally LEON FESTINGER, A THEORY OF COGNITIVE DisSONANCE 1-31 (1957).
} 
Directors' initial ignorance in this area might not matter very much if they possessed the time and incentive to develop the necessary expertise. But directorships are part-time positions. ${ }^{105}$ Most independent directors have other, very demanding positions elsewhere, and typically devote less than 200 hours per year to their directorial duties. ${ }^{106}$ Directors also lack the incentive to invest in acquiring the relevant information. Directors' compensation is generally a mix of cash salary, equity (whether in restricted stock or options), and benefits such as health insurance. ${ }^{107}$ While the equity portion of their compensation may help them internalize the corporation's interests to some degree, ${ }^{108}$ they are unlikely to own so much stock that a small difference in stock price would have much impact on their total wealth. While I argue both here and elsewhere that the CEO's compensation package, particularly its structure, can make a very large difference to the corporation's success, ${ }^{109}$ the conventional wisdom is that on a per-share basis, CEO compensation is insignificant to the value of the stock holdings of a given shareholder. ${ }^{110}$ The net result, therefore, is that the board possesses very little private information about the effectiveness of different compensation types.

105 See Bebchuk \& Fried, supra note 2, at 37; Dorff, supra note 3, at 266; Lorsch \& MacIver, supra note 67, at 23; ROBERT A. G. MONKS, CORPORATE GOVERNANCE 185 (2d ed. 2001).

${ }^{106}$ See supra note 105.

107 See Bebchuk \& Fried, supra note 2, at 25; Dorff, supra note 3, at 266; Elson, supra note 66 , at n.25.

${ }^{108}$ See Elson, supra note 66, at n.131; Bainbridge, supra note 14, at 9. This contention is subject to some debate. See Barris, supra note 2, at 65-66 (1992); Bebchuk \& Fried, supra note 2, at 196; Bogus, supra note 2, at 11-13; Mark J. Loewenstein, Reflections on Executive Compensation and a Modest Proposal for (Further) Reform, 50 SMU L REV 201, 206-208 (1996); Charles A. O'Reilly et al., CEO Compensation Tournament and Social Comparison: A Tale of Two Theories, 33 ADMIN. SCI. Q. 257, 266 (1988) (arguing there is only a modest positive effect); Charles M. Yablon, Bonus Questions-Executive Compensation in the Era of Pay for Performance, 75 NOTRE DAME L. REV. 271, 275 (1999).

109 See Dorff, supra note 3, at 259; Dorff, supra note 2, at 819.

${ }^{110}$ See, e.g., Mark J. Loewenstein, The Conundrum of Executive Compensation, 35 WAKE FOREST L. REV. 1, 11 (2000) (arguing that the amounts spent on executive compensation are immaterial); Kevin J. Murphy, Politics, Economics, and Executive Compensation, 63 U. CIN. L. REV. 713, 726 (1995) (same). 
The second criterion for a social cascade is that decisions are made in sequence, rather than simultaneously. ${ }^{111}$ Executive compensation decisions are made at different times by different corporations. Chief executive positions become available for a variety of reasons, from planned retirements to sudden terminations. As a result, CEOs' initial hiring - and concomitant compensation negotiation - can take place at any time during the year. Similarly, since CEOs are hired throughout the year, their contracts expire at different times. Renewal discussions and decisions therefore occur at different times as well. Because compensation decisions are not made simultaneously, each board may choose to imitate the example of the companies that preceded it, rather than follow its own private information about the efficiency of various compensation structures.

In addition, within an individual board, opinions may be expressed in a sequence that produces a social cascade. If the first few directors to speak on an issue have private information that points in the same direction - information they may have received from the CEO or the CEO's compensation consultant - the remaining directors may choose to follow their lead, despite possessing some data that point toward a different decision.

The two necessary factors for a social cascade - that participants have little private information and that they make their decisions in sequence - are present in the executive compensation context. Individual directors rarely possess or choose to acquire much scientific information about the incentive effects of different compensation plans, and boards make their executive compensation decisions throughout the year, not all at once.

A key factor in the understanding of executive compensation as the result of a social cascade is the role of the executive compensation consultant. Most large public corporations engage a compensation specialist as a consultant when formulating their executive pay packages. ${ }^{112}$ These consultants provide a comparison study, indicating the amount and form of compensation similar corporations pay their own CEOs. ${ }^{113}$ Such comparison studies effectively provide a report on what

\footnotetext{
${ }^{111}$ See Bikhchandani, supra note 17, at 153-54; Robert J. Shiller, Conversation, Information, and Herd Behavior, 85 AMER. ECON. REV. 181,181-83 (1995).

${ }^{112}$ See Bebchuk \& Fried, supra note 2, at 37, 70; Dorff, supra note 3, at 267; Yablon, supra note 108 , at n.5.

${ }^{113}$ See Dorff, supra note 3, at 267; Yablon, supra note 108, at n.5.
} 
other similarly situated boards of directors have done when faced with similar questions - how much should the corporation pay the CEO and how should the company structure the CEO's compensation? Although the preceding boards also possessed little private information about the effects of different incentive structures, the fact that so many boards have made very similar decisions - to reward the CEO lavishly and to include programs such as stock options, restricted stock, deferred compensation, and retirement benefits - is likely to induce a board to follow the crowd rather than investigate more deeply on its own.

One nagging question is why consultants do not provide correct, statistically validated information about which compensation techniques provide the greatest return for shareholders. BF's response - that consultants work for the person who hires them, the CEO - may prove the correct one here. Alternatively, consultants may tout the latest trend in compensation because they are part of a social cascade themselves (a cascade of consultants who follow a few leaders into error) or are the victims of a version of groupthink. The inherent difficulties in obtaining objective measures of executive performance, separate from other company-specific or industry-specific factors, may also play a large role here. ${ }^{114}$ One example that may illustrate the scope of the problem comes from the recent case of Brehm v. Eisner. ${ }^{115}$ In that case, one of the most outspoken and well-known critics of executive compensation practices, Graef Crystal, was consulted about Michael Ovitz's compensation package. ${ }^{116}$ Although Ovitz's arrangement resulted in Disney paying him well over $\$ 100$ million for about six months' work, Crystal reportedly did not object to the package. ${ }^{117}$

Consultants play a pivotal role in beginning and maintaining any cascade. Consultants communicate other boards' "moves" with respect to compensation. Without consultants' information, boards would have a more difficult time learning details about the structures of other corporations' executive compensation packages. Although federal

\footnotetext{
${ }^{114}$ See BoK, supra note 2, at 96.

${ }^{115}$ Brehm v. Eisner, 746 A.2d 244 (DE Sup. Ct. 2000)

${ }^{116} \mathrm{Id}$. at 251 .

${ }^{117}$ Id. at 251, 260. See also Chad Bray, Pay Expert Calls Disney-Ovitz Pact “Unreasonable”, WALL ST. J., Oct. 26, 2004 at B6; Bruce Orwall \& Chad Bray, Ovitz's Testimony on Disney Tenure Portrays a Thwarted Deal Maker, WALL St. J., Oct. 27, 2004, at A1.
} 
securities regulations require corporations to disclose some information, significant aspects of compensation plans are generally missing. ${ }^{118}$

Unlike the incentives produced by the power dynamics hypothesized by Managerial Power Theory, social cascades rooted in information externalities are fragile; they can be shattered fairly easily by the release of new information. ${ }^{119}$ The cascade endures only while the participants remain uncertain about the correct decision. If that uncertainty dissipates, the rationale for relying on others' choices - that we can deduce their private information by observing their actions collapses. $^{120}$

To the extent inefficient payment mechanisms are sustained by information externality social cascades, then, they must be supported by rationales that are at least facially credible. A compensation device that is transparently inefficient should not be the result of a social cascade. Even with very limited private information, directors who can easily perceive the problems with a mechanism should avoid it.

A cascade rooted in reputational concerns might prove less vulnerable to new information, or at least to some types of new information. ${ }^{121}$ Remember our teenager in the music store. ${ }^{122}$ Providing her with objective information that the Postal Service album is much better than Gwen Stefani's, and that she will enjoy it much more, is unlikely to shift her decision (even if aesthetics could be objectively determined or demonstrated). She chose the Gwen Stefani album not because she thought she would prefer their music, but because she feared her friends would mock her if she exercised her true preferences. New information would be likely to shift her choice only if it changed her peers' likely reaction. For example, if another, very popular teenager, one who our teenager's friends all deferred to, told our teenager that Gwen Stefani was no longer hip, and that all the cool kids were listening to the Black Eyed Peas, our teenager might well decide to buy the Black Eyed Peas' music instead.

Reputational concerns may play some role in boards' compensation decisions. Directors seem unlikely to adopt a compensation mechanism that their peers at other corporations would

\footnotetext{
${ }^{118}$ See Bebchuk \& Fried, supra note 2, at 67-68.

${ }^{119}$ See Bikhchandani, supra note 17, at 157-8.

${ }^{120} \mathrm{Id}$. at 151 ; Banerjee, supra note 18 , at 798 .

${ }^{121}$ See Sunstein, supra note 16, at 78 (describing reputational cascades).

${ }^{122}$ See supra note 88 and surrounding text.
} 
consider unorthodox or strange. Such a decision would attract the attention of the financial press and display directors in a poor light, perhaps damaging their full-time careers and reducing their opportunities to serve on additional boards.

But the reputational effects of compensation decisions seem vulnerable to proof of the efficiency or inefficiency of a particular payment mechanism. Unlike our teenager's ethereal goal of appearing cool, directors' task is the somewhat more tangible duty to manage the corporation on the shareholders' behalf. ${ }^{123}$ In the absence of some psychological impediment such as groupthink, directors' peers should value payment mechanisms that improve the company's prospects, and should laud those boards who adopt them. Even if a payment mechanism is considered outré, it should readily find the group's favor if evidence is presented that the device provides maximum executive motivation at a minimal cost. Since directors' peer group should care about actual incentive effects, and not the aesthetics or social acceptability of a particular approach, directors who care about their reputations with that group should feel similarly. That is, directors who want to enhance their reputations as competent corporate stewards should seek out the most efficient payment mechanisms, based on the best available evidence, regardless of whether those methods are currently popular. If they are efficient, they will quickly become popular, and the early adopters will be celebrated for their vision. For this reason, reputation-based social cascades should not account for many compensation package inefficiencies. ${ }^{124}$

If reputation-based social cascades are unlikely to produce compensation package inefficiencies, and if information externalitybased social cascades are vulnerable to persuasive evidence of

${ }^{123}$ See, e.g., Revlon, Inc. v. MacAndrews \& Forbes Holdings, Inc., 506 A.2d 173, 179 (Del. 1986); Alpert v. 28 Williams Street Corp., 63 N.Y.2d 557, 568 (1984).

${ }^{124}$ There is some contrary evidence that even groups who should care only about efficiency may, under some conditions, stick with traditional approaches that are demonstrably suboptimal. See John Coates, Explaining Variation In Takeover Defenses: Blame The Lawyers, 89 CALIF. L. REV. 1301 (2001) (finding that even large, sophisticated law firms faced with very large transactions made poor decisions about whether to adopt takeover defenses that were based on tradition rather than the optimal choices for their clients); David Romer, Do Firms Maximize? Evidence From Professional Football, available at http://elsa.berkeley.edu/ dromer/papers/PAPER_NFL_JULY05_FORWEB_CORREC TED.pdf (last viewed on Aug. 29, 2006) at 28-33 (similar findings for professional football coaches). If boards act this way, reputation concerns could cause a cascade. 
inefficiencies, how much explanatory power can social cascades possess?

Social cascades (rooted in information externalities) may explain many of the inefficiencies we observe if no new, persuasive information typically arises to collapse the cascade. At first glance, this premise seems fanciful. Literally billions of dollars are spent by public corporations compensating their senior management teams each year, representing nearly $10 \%$ of those companies' earnings. ${ }^{125}$ Surely directors have an enormous incentive to research (or pay academics to research) whether the compensation devices that are popular are also efficient.

In thinking about corporate governance problems, it is important to remember that directors do not always share the corporation's incentives. Even if CEOs have not captured directors, boards still retain certain structural flaws - such as problems of composition, incentive, and resources - that may prevent directors from actively pursuing the corporation's best interests. ${ }^{126}$

In the case of executive compensation, Managerial Power Theory asserts (correctly, I believe) that directors have little direct financial incentive to search for the optimal pay structure. ${ }^{127}$ The small incentive that does exist might suffice if it were simple to identify the most efficient compensation devices. If directors had only to ask their consultant to receive an authoritative and correct answer, perhaps we would have good reason to doubt that social cascades form in this area. Unfortunately, it is quite difficult to determine which structures are efficient. Many of the devices BF aptly criticize appear at first blush to be highly efficient and have been lauded by sophisticated (and presumably impartial) academics. For example, stock options, which BF lambaste as, inter alia, rewarding executives for general increases in the stock market unrelated to their own performance, ${ }^{128}$ are defended by academics as an excellent method of reducing agency costs. ${ }^{129}$

\footnotetext{
${ }^{125}$ See Lucian Bebchuk \& Yaniv Grinstein, The Growth of Executive Pay, 21 OxFORD REVIEW OF ECONOMIC POLICY 283, 297 (2005) (finding that the top five managers at substantial (market capitalization over $\$ 50$ million) public corporations were paid an average of $9.8 \%$ of earnings from 2001-2003).

${ }^{126}$ See Dorff, supra note 2, at 843-54.

${ }^{127}$ Id. at $854-55$.

${ }^{128}$ See Bebchuk \& Fried, supra note 2, at 139.

${ }^{129}$ See infra notes 183-189; see also Arthur H. Dean, Employee Stock Options, 66 HARV. L. REV. 1403 (1953).
} 
Similarly, restricted stock, which BF argue share the same performance insensitivity as options, ${ }^{130}$ have been advocated by well-respected academics such as Charles Elson. ${ }^{131}$ Even now, BF's contentions that these devices are inefficient remain hotly contested. ${ }^{132}$

As a result of the difficulty of proving conclusively whether a compensation method is efficient or not, social cascades in the executive compensation area may turn out to be quite robust. New information may call the conventional wisdom into question, but the resulting uncertainty may cause directors to be more reliant on other boards' actions, not less. Social cascades seem quite likely to form and endure in this environment.

In addition, once a cascade has taken hold, the resulting decision may take on the legitimacy of the market. Directors, executives and compensation consultants who wish to argue for alternative compensation structures will then have to overcome the powerful argument that the market has determined the traditional compensation forms are efficient. Moreover, to compete for talented executives, corporations may have to offer the same inefficient (but management favoring) payment mechanisms offered by their peer companies.

Recent events provided a dramatic illustration of this phenomenon. When the bankruptcy court judge presiding over United Airlines' Chapter 11 filing approved the executives' new, very lucrative pay package, the court responded to objections that the executives' pay was excessive by stating:

It may be we have a culture in this country that overcompensates management, but United is just one enterprise that operates in that general environment ... .The marketplace indicates this is a reasonable plan. ${ }^{133}$

Whatever we may believe about managers' influence over boards, that power is not very likely to extend to a federal bankruptcy judge. Yet the presumably impartial and independent judge felt he had

\footnotetext{
${ }^{130}$ See Bebchuk \& Fried, supra note 2, at 170-73.

131 See Elson, supra note 66, at 944.

${ }^{132}$ See John Biggs, Executive Compensation: Perspectives From a Former CEO, $30 \mathrm{~J}$. CORP. L. 755, 757 (2005) (arguing in favor of restricted stock).

${ }^{133}$ See Susan Carey, Judge Approves UAL's Managers Incentive Plan, WALL STREET JOURNAL, January 19, 2006, A2.
} 
to bow to the market, even though he seemed to believe that the market was overcompensating executives. The rhetorical legitimacy of the market can be incredibly difficult to overcome and may produce unusually stable social cascades.

There are limits to the explanatory power of cascades, however. If a choice is obviously incorrect, participants with even minimal private information will know better than to select it. ${ }^{134}$ Compensation devices that are patently foolish, then, could not be chosen as the result of a social cascade. Social cascades can plausibly explain only those pay structures that seem reasonable, at least on the surface, or which are so complex that directors are unlikely to invest the necessary effort or resources to comprehend their likely effects.

Many common devices seem to fit this criterion, but not all. Bonuses, stock options, restricted stock, the freedom to unwind equity incentives, retirement pay and deferred compensation, company loans and soft landings for failures may all be the result of social cascades. In contrast, cascades seem unlikely to be the cause of corporation's award of what BF term "gratuitous payments," (though these may be caused by groupthink). ${ }^{135}$

In the following section, I will briefly explain why each of these compensation methods may appear reasonable, and why the arguments on either side seem difficult to resolve conclusively. Groupthink boards - especially if led by self-consciously manipulative CEOs - may therefore easily fall prey to arguments in favor of such compensation devices. Also, faced with great uncertainty, even well-functioning boards may rationally respond by following the lead of their peer corporations and ignoring whatever private misgivings they might have. The juxtaposition of this lack of private information with the ability to observe what similarly situated others have already chosen may produce a social cascade that results in boards adopting inefficient payment mechanisms. $^{136}$

\footnotetext{
${ }^{134}$ A participant might select an option she or he knew to be incorrect in order to garner the praise of his or her peers (as with the teenager in the music store). As explained above, I believe any social cascades in the executive compensation area are most likely to be caused (at least primarily) by information externalities, and not fear of social opprobrium. ${ }^{135}$ See Bebchuk \& Fried, supra note 2, at 87.

${ }^{136}$ See supra notes 102, 111.
} 
III. Accounting for Inefficient Compensation Methods

Groups often make poor decisions, even when their members are individually sophisticated, intelligent, and well-educated. Groupthink and social cascades provide an account of why certain types of groups or groups facing certain circumstances - are particularly likely to make deficient choices. I have argued in the previous section that public company boards crafting their CEOs' compensation are likely to suffer from groupthink. I have also argued that chief executive pay is an arena that may be experiencing a social cascade. Either phenomenon or a combination of the two may explain why public company boards have adopted the inefficient payment devices BF have exposed. Boards may be reaching poor conclusions because of well-recognized problems with group decision-making, rather than because of the CEOs' power and the directors' cupidity. Directors may honestly (though erroneously) believe that they are adopting payment mechanisms that tie CEOs' pay to their performance.

For either groupthink or a social cascade to produce an incorrect decision, the decision should not be obvious. While groupthink is sufficiently powerful to occasionally generate even apparent errors, as Asch's experiments famously demonstrated, inconspicuous errors are more likely to slip through. It is easier to justify a choice that may be correct than one is that is clearly mistaken. Social cascades acting alone should never produce results that are clearly wrong, since the basis of a cascade is a lack of information and not pressure to conform to a group decision. Both phenomena should therefore prove most powerful when the decision at issue has no clear right or wrong answer.

Nearly all of the payment devices BF identify fall into this category. BF argue powerfully that bonus plans, stock options, restricted stock, freedom to unwind equity incentives, retirement pay, company loans, and soft landings for failures are inefficient, at least in the forms in which boards have traditionally employed them. (Gratuitous payments represent a special case, as I will explain below.) But their arguments are subtle, complex, and - most importantly - hotly disputed by experts in the field. The resulting confusion creates a situation ripe for groupthink or a social cascade to produce a suboptimal incentive structure for CEOs. In this section, I will take the compensation mechanisms BF argue are inefficient one by one. For each, I will briefly summarize BF's exposure of the device's weaknesses and then explain 
why these weaknesses are far from obvious, so that boards' use of the devices may be explained by Group Dynamics Theory.

Because groupthink and social cascades hinge on common factual support - the facial reasonableness of each compensation method - it may prove difficult to distinguish which phenomenon is operating. My point in this paper is not to isolate the particular cause of any given flaw in executive compensation. I suspect that several dynamics including managerial power - are operating simultaneously to produce the observed results. For example, a board's susceptibility to groupthink may increase when the CEO holds power over the directors. Groups are more likely to succumb to groupthink when they have powerful and charismatic leaders, so we should expect a greater degree of groupthink among corporations whose CEOs play a larger role in choosing the corporation's slate of directorial nominees. ${ }^{137}$ My goal here is to demonstrate that ample evidence exists to suggest that Group Dynamics Theory is, at the least, an important contributing factor to the problems we observe in the executive compensation system and may be the most important factor. Any reform agenda must therefore include proposals that target group dynamics. ${ }^{138}$

\section{$\underline{\text { A. Bonus Plans }}$}

\section{Managerial Power Theory}

Bonus plans would appear to present an ideal compensation structure. If executives know in advance they will receive extra compensation for achieving certain goals, they will likely work harder to achieve those goals. This is precisely the purpose of compensation - to reduce agency costs by aligning workers' motives with those of their employers. To maximize their effectiveness, though, bonuses should be triggered by measures of individual performance, not the performance of

\footnotetext{
${ }^{137}$ See supra note 75.

${ }^{138}$ I will not attempt, in this short space, to present Optimal Contracting Theory's defense of these features. For those readers interested in such a defense, I highly recommend the excellent work of such scholars as Stephen Bainbridge, Jeffrey Gordon, Kevin Murphy and Randall Thomas. See supra note 14. Throughout this Article, I assume that $\mathrm{BF}$ have correctly identified inefficiencies in executive compensation contracts. Again, my purpose here is not to quarrel with BF's evidence, or with the need for changes in the law, but rather to argue for an alternative explanation for the problems they have aptly identified and to propose a supplemental reform agenda.
} 
the corporation as a whole. ${ }^{139}$ In addition, the performance measures should compare an executive's achievements to those of his or her peers at competing companies. ${ }^{140}$ Otherwise, corporate officers may be rewarded for results they did not produce, that may be due to marketwide effects rather than individual effort. ${ }^{141}$

$\mathrm{BF}$ contend that boards have warped bonus structures to meet their own purposes. ${ }^{142}$ In order to please the senior managers who will determine if they retain their positions, directors have awarded bonuses based on objective targets that represent only mediocre performance (such as meeting a budget), or which have little to do with the executive's own actions (such as increases in the firm's stock price). ${ }^{143}$ Directors have also made bonuses dependent on certain subjective criteria, such as effective leadership, which are easily manipulated by captive boards. ${ }^{144}$ Boards have even lowered bonus thresholds when it became clear that executives would not meet them. ${ }^{145}$

These actions are difficult to explain if boards bargain at armslength with executives over their pay. Independent boards should insist on conditioning bonuses on individual executive achievements, not luck. For example, an oil company executive should not be rewarded for an increase in the market price of oil that produces increased company profits. No effort of the executive produced the shift in market prices, yet boards' bonus plans frequently reward increases in company profits that result from external effects like this one. ${ }^{146}$

\footnotetext{
${ }^{139}$ See Bebchuk \& Fried, supra note 2, at 121-36 (discussing non-equity-based compensation).

${ }^{140} I d$. at 122 (noting that empirical work has failed to find a strong correlation between cash compensation and managers' performance relative to their respective industries).

${ }^{141} I d$. at 123 (citing a study showing that managers were paid the same for a "lucky" dollar (as in increase in oil prices) as for a "general" dollar (a dollar that was not generated by such luck)); See also Marianne Bertrand and Sendhil Mullainathan, Are CEOs Rewarded for Luck? The Ones without Principals Are, 116 Q. J. OF ECON. 901, 901-32 (2001).

${ }^{142}$ See BEBCHUK \& FRIED, supra note 2, at 121-36 (discussing bonus structures and criteria).

${ }^{143} I d$. at $122-27$ (noting that CEO cash compensation is strongly correlated with market-wide stock price increases).

${ }^{144} I d$. at 126.

${ }^{145} I d$. at 127 (citing Richard Trigauz, Great Disconnect, ST. Petersburg Times, May 26, 2002, at 1H; Louis Lavelle, Executive Pay, Bus. WK., Apr. 15, 2002, at 84; David Leonhardt, Coke Rewrote Rules, Aiding Boss, N.Y. Times, Apr. 7, 2002, at sec. 3, 6.). ${ }^{146}$ See supra note 141.
} 
$\mathrm{BF}$ argue that observed bonus plans are better explained by their Managerial Power theory. ${ }^{147}$ Boards use bonus plans as useful camouflage to disguise funneling excessive compensation to chief executives. ${ }^{148}$ If pressed, directors can assert that the compensation was earned by the executive's superior performance, even though in fact the bonus was triggered by goals that may have had little, if anything, to do with the executive's own actions. ${ }^{149}$

\section{Group Dynamics Theory}

Although BF make a powerful case that public company boards currently use bonuses poorly, there are also strong arguments that the traditional forms of bonuses are efficient. Bonuses are not only common for non-executive employees, but they appear on their face to be strongly related to individual performance. Tying bonuses to the company's stock price, the measure of corporate performance most important to shareholders, might be an efficient method of motivating the CEO to focus on what should be his or her most important goal. Choosing narrower goals, such as performance within budget or successful leadership, appears to be a reasonable attempt to address one of BF's core concerns, the disconnect between CEOs' individual performance and their compensation. ${ }^{150}$

Although effective leadership is a subjective criterion, board members - especially those who are themselves chief executives of large corporations - are likely to believe themselves capable of accurate judgment. Because of the egocentric bias, they may actually have greater faith in their own ability to evaluate the CEO's success than they do in objective measures such as earnings per share or stock price. ${ }^{151}$ As $\mathrm{BF}$ point out, these objective goals may be met despite inadequate

\footnotetext{
${ }^{147}$ See BEBCHUK \& FRIED, supra note 2, at 121-22.

${ }^{148} I d$. at $67-68$.

${ }^{149} \mathrm{Id}$., at $135-36$

${ }^{150} \mathrm{Id}$. at 126.

${ }^{151}$ The egocentric bias refers to people's tendency, "to view available evidence as being more supportive of their beliefs and positions than is objectively appropriate, to overestimate their own skills and abilities, and to be unrealistically optimistic about future life events." Russell Korobkin, Aspirations and Settlement, 88 CORNELL L. REV. $1,12(2002)$.
} 
leadership, or missed despite outstanding performance. ${ }^{152}$ Subjective criteria permit board members to account for all the difficulties the CEO did (or did not) overcome.

In sum, bonuses appear reasonable on their face, and the arguments that they are inefficient are complex and difficult to resolve conclusively. As a result, boards may resolve the associated difficulties by deferring to the CEO, producing groupthink. Alternatively, the board may turn to peer corporations and mimic their behavior, resulting in a social cascade. In either event, the directors may choose a bonus plan that is less than ideal as a result of a flaw in their decision-making process.

\section{B. Structure of Options}

\section{Managerial Power Theory}

BF attack stock options as yet another method of disguising excessive pay as performance-based. ${ }^{153}$ In the past ten years, stock options have arguably become the single most important form of executive compensation, accounting for a larger percentage of total compensation than even salaries or bonuses. ${ }^{154}$ Many scholars have applauded the rise of options, arguing that equity ownership is the best method to align the interests of managers with those of shareholders. ${ }^{155}$ Although BF acknowledge options provide some positive incentive effects, ${ }^{156}$ they contend that too many stock options are granted, rewarding CEOs more than necessary to purchase their services. ${ }^{157}$ More importantly from an incentives perspective, options are designed poorly if their purpose is to reward managers for their efforts in

\footnotetext{
152 See BEBCHUK \& FRIED, supra note 2, at 124-27.

${ }^{153} \mathrm{Id}$. at $137-85$.

${ }^{154}$ For S\&P 500 firms, the salary portion of CEO compensation declined from $36 \%$ to $21 \%$ of total compensation from 1992-98. The option-based portion of CEO compensation increased from 22\% to 38\% from 1992-98 in S\&P 500 firms. See Perry \& Zenner, supra note 2, at 131. See also Barris, supra note 2, at 64 (stating that options increased as a percentage of total compensation from $8 \%$ in 1985 to $31 \%$ in 1991).

155 See infra notes 183-189.

${ }^{156}$ BEBCHUK \& FRIED, supra note 2, at 137 (supporting general idea of equity-based compensation).

${ }^{157} \mathrm{Id}$. at 138 .
} 
improving corporate performance. ${ }^{158}$ Stock options are a blunt instrument; they enrich managers for their successful efforts, but they also reward employees for growth in the industry generally, improvements in the economy, changes in interest rates, and other external causes of growth. ${ }^{159}$ Relatively simple changes in option design could eliminate many, though perhaps not all, of these windfall profits. ${ }^{160}$ For example, the options' exercise price could be determined by reference to an industry or market index. ${ }^{161}$ The exercise price would then increase when the index increased, so that the options would only become valuable if the corporation performed better than the average large corporation (if indexed to the market as a whole) or better than its average competitor (if indexed to an industry index). ${ }^{162}$ Despite the simplicity and apparent efficiency of utilizing such indexed options, however, few options are indexed. ${ }^{163}$

Three other common board behaviors in managing options seem better explained by boards' capture than by their efficiency. First, boards nearly universally set the options' exercise price at the market price the day the options are granted. ${ }^{164} \mathrm{BF}$ question why that precise price should always generate the most optimal incentives. ${ }^{165}$ While setting the strike price below the market price ("in the money" options) would have adverse tax consequences, ${ }^{166}$ there is no similarly obvious explanation for most corporations' failure to set the exercise price above market ("out of the money"). ${ }^{167}$

${ }^{158} I d$.

${ }^{159}$ Id. at 139; see also Saul Levmore, Puzzling Stock Options and Compensation Norms, 149 U. PA. L. REV. 1901, 1901-40 (2001) (discussing stock options in general). ${ }^{160}$ See BEBCHUK \& FRIED, supra note 2, at 140-43 (arguing companies could at least filter out changes due to sector or general stock market trends by measuring the company's performance relative to easily calculated benchmarks).

${ }^{161} I d$. at $141-42$.

${ }^{162} \mathrm{Id}$.

${ }^{163} \mathrm{Id}$. at 143 (noting that in 2002, only $8.5 \%$ of large public firms issuing options to executives conditioned even a portion of the grant on performance).

${ }^{164} I d$. at $159-62$ (stating that strike price is set at stock price on date of the grant $95 \%$ of the time).

${ }^{165} \mathrm{Id}$. at 162 .

${ }^{166} . I d$. at 160 (noting that in-the-money options are not deductible because they are not performance-based compensation). See also Anabtawi, supra note 42, at 1571 (discussing option repricing).

${ }^{167}$ See BEBCHUK \& FRIED, supra note 2, at 160-61 (contending that out-of-the-money options often generate much higher pay-for-performance sensitivity per dollar of expected value than conventional options); but see Anabtawi, supra note 170, at 1571- 
Second, boards frequently lower the exercise price of previously issued options when the stock market as a whole declines, either directly or by issuing replacement options with a lower strike price. ${ }^{168}$ Although repricing options is sometimes justified as necessary to preserve executives' incentives, or to prevent them from leaving the firm, BF argue that indexed options would achieve the same goals. ${ }^{169}$ Companies' willingness to reduce options' exercise price when the stock market as a whole declines, and not increase exercise price when it rises, seems to support the Managerial Power hypothesis. ${ }^{170}$

Third, when executives exercise their stock options, many corporations automatically "reload" the options, granting the managers new options with an exercise price set at the market price on the grant date. ${ }^{171}$ Reload options are very valuable, because they enable employees to profit from an increase in the company's stock price without giving up the potential to earn even more money if the stock continues to rise. ${ }^{172}$ Like repricing, reload options are sometimes justified by citing the need to preserve executives' incentive. ${ }^{173}$ Once executives have exercised their options and sold the resulting stock, the options lose their incentive effect; managers without a significant equity stake in the company are more likely to have interests that diverge from shareholders'. BF counter that it would be easier to achieve this goal by restricting executives' ability to sell their company stock. ${ }^{174}$ Instead, reload options permit senior managers to profit from stock price volatility and to receive additional compensation that is not related to their performance. ${ }^{175}$ In short, reload options do a poor job of motivating performance. Their popularity among boards despite their flaws may suggest some improper directorial motive. ${ }^{176}$

74 (arguing that option price too far out-of-the-money option are ineffective). See also infra notes 190-191 and associated text.

${ }^{168}$ See BEBCHUK \& FRIED, supra note 2, at 164-67 (arguing that this further reduces the link between pay and performance).

${ }^{169} \mathrm{Id}$. at 166.

${ }^{170}$ Id. at 164-68 (citing Menachem Brenner, Rangarajan K. Sundaram, and David Yermack, Altering the Terms of Executive Stock Options, 57 J. FIN. ECON. 103, 110 (2000)).

${ }^{171} I d$. at 169 .

${ }^{172} I d$.

${ }^{173} \mathrm{Id}$.

${ }^{174}$ Id.

${ }^{175} \mathrm{Id}$. at 170 .

${ }^{176} I d$. 


\section{Group Dynamics Theory}

Although BF again make some very strong arguments that conventional options could be much better designed to motivate CEOs, other experts disagree. Stock options still inspire passionate defenders today. ${ }^{177}$ Their essential justification is that executives should be induced to care about what matters most to shareholders - stock price. ${ }^{178}$ Options appear to achieve this end by rewarding executives exactly in proportion to the increase in the company's share price. Most corporations set their options' exercise price at the market price as of the date the options are granted. ${ }^{179}$ If the stock price then rises, optionholders share shareholders' resulting profits; the more the stock price increases, the more option-holders profit. ${ }^{180}$ The basic idea behind options, then, seems perfectly reasonable.

As BF point out, though, some common features of options require further explication. The failure to index options might be explained by groupthink or cascades. Not only do ordinary (nonindexed) options have obvious intuitive appeal, but as BF acknowledge, many scholars have argued that ordinary options are more efficient than indexed options. ${ }^{181}$ For example, commentators have argued that indexed options would create distortions in the employment market, by

\footnotetext{
${ }^{177}$ See infra notes 183-185.

${ }^{178}$ See Lynn A. Stout, The Mechanisms of Market Inefficency: An Introduction to the New Finance, 28 J. CORP. L. 635, 639 (2003) (discussing the recent enthusiasm for "incentivizing" corporate officers with options); Matthew A. Melone, Are Compensatory Stock Options Worth Reforming?, 38 GONZ. L. REV. 535, 537 (2002/2003) (discussing stock options as incentive compensation).

179 See supra note 1644 .

${ }^{180} \mathrm{Id}$.

${ }^{181}$ See BEBCHUK \& FRIED, supra note 2, at 147-58 (discussing commentators); see also Levmore, supra note 159, at 1922-24; Charles P. Himmelberg and R. Glenn Hubbard, Incentive Pay and the Market for CEOs: An analysis of Pay-for-Performance Sensitivity at 2 (June 2000), available at http://www0.gsb.columbia.edu/faculty/ghubbard/Papers/ceo10.pdf; Li Jin, CEO Compensation, Diversification and Incentives at 25, working paper (2000), available at http://ssrn.com/abstract=254260; Kevin Murphy, Explaining Executive Compensation: Managerial Power Versus The Perceived Cost Of Stock Options, 69 U. CHI. L. REV. 847, 863 (2002); David M. Schizer, Tax Constraints on Indexed Options, 149 U. PA. L. REV., 1941, 1942-43 (2001).
} 
providing executives with an incentive to less competitive sectors. ${ }^{182}$ Other academics have contended that indexed options would induce CEOs to take excessive risks in an effort to race ahead of their competitors; ${ }^{183}$ that conventional options help retain managers by automatically increasing their pay during periods of economic prosperity, when the competition for executives may be at its most fierce, ${ }^{184}$ that indexed options would impose too much risk on executives; ${ }^{185}$ that non-indexed options are equivalent to providing executives with a degree of desirable diversification through implicit investment in the broader market; ${ }^{186}$ and that ordinary options may provide a method of avoiding the $\$ 1$ million deductibility cap on compensation that is not performance related. ${ }^{187}$

${ }^{182}$ See Surya N. Janakiraman, et. al, An Empirical Investigation of the Relative Performance Evlauaiton Hypothesis, 30 J. ACCOUNTING RESEARCH 53, 67 (1992); Ronald A. Dye, Relative Performance Evaluation and Project Selection, $30 \mathrm{~J}$. ACCOUNTING RESEARCH 27, 28 (1992).

${ }^{183}$ See Levmore, supra note 159, at 1922-24.

${ }^{184}$ See Himmelberg and Hubbard, supra note 181, at 2 (arguing that conventional options help retain talented managers during market booms; the better the market does, the higher the demand for executives, and the more companies must pay CEOs to retain them; conventional options do this automatically by going up when market increases); see also Paul Oyer, Why Do Firms Use Incentives that Have No Incentive Effects? at 12, Stanford University Graduate School of Business working paper (2000), available at http://faculty-gsb.stanford.edu/oyer/wp/luck.pdf (presenting a model in which it is optimal to pay individuals for group-level, industry-level, or economy-wide performance because agents' opportunities are correlated with aggregate performance and it is costly to adjust terms of employment contracts).

${ }^{185}$ See Murphy, supra note 181, at 862-63 (arguing that indexed options would impose too much additional risk of nonpayment on risk-averse executives; reporting that the probability that a given stock will earn returns in excess of a value-weighted index is below $50 \%$, while there is an $80 \%$ chance that by the time a ten-year conventional option expires, the stock price will exceed the exercise price).

${ }^{186}$ See BEBCHUK \& FRIED, supra note 2, at 137-38; see also Jin, supra note 181, at 25 (observing that indexing shifts market risk back to shareholders who might also be risk averse, and thus that from a pure risk-sharing perspective the optimal contract might not involve indexing).

${ }^{187} 26$ USC § 162m (1994). See Schizer, supra note 181, at 1942-43 (noting that conventional options have a potential tax advantage over indexed because they give managers nonperformance value that the company can still deduct even if over $\$ 1$ million in pay; observing too, however, that firms have largely avoided indexed options even when there was no tax advantage to delivering performance-decoupled pay through conventional options, as was the case before 1994 when there was no limit on pay deductibility). 
BF have eloquent and thoughtful responses to these arguments and others. But even impartial scholars in the field find these issues muddy. Directors - whose primary expertise almost always lies in areas other than executive compensation - cannot be expected to feel certain that indexed options are clearly superior to the conventional variety. As a result, even a fairly intense investigation of the topic might ultimately be resolved by the response - especially if uttered by a trusted expert such as a compensation consultant - that "everyone else is doing it," producing a social cascade. Also, the question is sufficiently close that a board suffering from groupthink should have no trouble agreeing with a $\mathrm{CEO}$ who argues that conventional options are superior.

Boards' tendency to set strike prices at market may similarly be explained by groupthink or social cascades. ${ }^{188} \mathrm{BF}$ correctly point out that the optimal strike price should vary based on the particular circumstances of the company and its executives. ${ }^{189}$ A small, rapidly growing company, for example, whose stock is already expected to increase quickly, might want to set exercise prices considerably above market, to reward executives only for performance that is greater than predicted. Setting a higher exercise price, though, risks eliminating the incentive altogether. ${ }^{190}$ If the strike price seems unreachable, executives may not try at all, defeating the whole purpose of granting options. ${ }^{191}$ In addition, in competing for employees with companies that offer at-themarket options, a company that wishes to set strike prices significantly above market will have to offer potential employees many more options to make up for the increased risk that the options will prove worthless. ${ }^{192}$

\footnotetext{
${ }^{188}$ See supra note 164 (discussing boards' tendency to set strike price at market).

${ }^{189}$ See BEBCHUK \& FRIED, supra note 2, at 159-62.

${ }^{190}$ See Anabtawi, supra note 42, at 1571 ("An executive whose options are severely underwater may believe that no amount of effort will bring the options back into the money, effectively severing the link between pay and performance as to those options.")

${ }^{191} I d$. This argument does not explain, however, why so few companies set strike prices even a little above the market price. See also Levmore, supra note 159, at 1924 (discussing diminished incentive function of options priced well out-of-the-money). ${ }^{192}$ See Edmond T. FitzGerald, Public Company CEO Compensation: A Review Of The Recent Reforms, 1433 PLI/Corp 441, 463 (2004); Levmore, supra note 159, at 1924 (discussing the necessity of raising pay or granting more options to compensate for increased risk imposed by them); see also Patrick Bolton, Jose Scheinkman, and Wei Xiong, Pay for Short-Term Performance: Executive Compensation in Speculative Markets, 30 J. CORP. L. 721, 739-40 (2005) (citing Abel Cadenillas et al., Leverage Decision and Manager Compensation with Choices of Effort and Volatility, 73 J. FIN.
} 
Shareholders of such a company face the potential for significantly greater dilution of their stock. ${ }^{193}$ The choice between the incentive benefits of an above-market exercise price and the associated dilution risks is far from obvious. Faced with such a difficult and complex decision, boards are quite likely to mimic what their peers have done, generating a social cascade.

There are also reasonable justifications for lowering options' strike price when the market as a whole declines. ${ }^{194}$ As Iman Anabtawi has explained, when market prices decline too far below the exercise price, the options lose their power to motivate and retain executives. ${ }^{195}$ Executives whose options are too far "underwater" may simply write them off as worthless. Valuable options may help to retain employees by imposing a large exit cost; employees who leave before their options vest forfeit them. ${ }^{196}$ Options that are deeply underwater, however, lose their deterrent value. ${ }^{197}$ Repricing options may be justified, then, as necessary to retain executives and preserve their incentive to raise the company's stock price. Again, I am not suggesting that repricing is always or even usually the best strategy for boards to take, only that the correct decision is sufficiently unclear to create an environment amenable to groupthink or a social cascade. ${ }^{198}$

ECON. 71, 84-87 (2003) and Brian Hall \& Kevin Murphy, Stock Options for Undiversified Executives, 33 J. ACCT. \& ECON., 3, 33-35 (2002) demonstrating that it is difficult to calculate how much more incentive is provided by out-of-the-money options), therefore it may not be worth the added expense of granting more options to compensate for increased risk).

${ }^{193}$ See FitzGerald , supra note 192, at 463. See also Randall S. Thomas and Kenneth J. Martin, The Determinants of Shareholder Voting on Stock Option Plans, 35 WAKE FOREST L. REV. 31, 59-60 (2000) (discussing potential dilutive effect of stock options on existing shareholders).

${ }^{194}$ See BEBCHUK \& FRIED, supra note 2, at 166.

${ }^{195}$ See Anabtawi, supra note 42, at 1571; see also Viral V. Acharya et al., On the Optimality of Resetting Executive Stock Options, 57 J. FIN. ECON. 65, 66-67 (2000)

${ }^{196}$ See Anabtawi, supra note 42, at 1572.

${ }^{197}$ Id. at 1571 .

198 Anabatawi also points out that boards reprice executives' options in response to firm-specific problems more often than in reaction to industry-wide or market-wide events, citing Li Jin \& Lisa Meulbroek, Do Underwater Executive Stock Options Still Align Incentives?: The Effect of Stock Price Movements on Managerial-Incentive Alignment, 9-10 (Harvard Bus. Sch., Working Paper 02-002, 2001). Anabatawi, supra note 42, at 1573. Jin and Meulbroek in turn cite for this finding to a study by Carter and Lynch, M.E. Carter and L. J. Lynch, An Examination of Executive Stock Option Repricing, 61 J FIN ECON 207, 207-225 (2001). Anabtawi argues that this study 
The final troubling aspect of options - reload features - may also be produced by groupthink or by social cascades. Reload options are clearly highly desirable for employees, since they permit option holders to lock in current gains while still preserving the possibility of further advances. ${ }^{199}$ At the same time, as Kevin Murphy has argued, boards may perceive reload options as a low-cost method of compensating executives, since they cost the company no cash and do not require an accounting charge. ${ }^{200}$ Since reload options appear to provide a low-cost method of providing high-value compensation, boards may believe they are desirable, despite their high actual costs. ${ }^{201}$ In addition, champions of reload options have argued that they promote employee stock ownership, by encouraging executives to exercise their options earlier. ${ }^{202}$ Faced with complicated and conflicting evidence as to the efficiency of reload options, boards might well choose to follow their CEO's lead (in a groupthink board) or to imitate their peers (producing a social cascade).

\section{Restricted Stock}

\section{Managerial Power Theory}

After discussing the problems with options, some commentators, most notably Charles Elson, have advocated substituting restricted stock. $^{203}$ Elson argues that grants of restricted stock align managers'

supports the managerial power explanation of repricing. Jin and Meulbroek themselves, however, argue that the explanation lies in people's inability to distinguish between individual talent and environmental factors in determining the cause of success. This explanation is entirely consistent with the social cascade explanation. Directors who possess little information as to the cause of a stock price decline, and who are faced with conflicting research as the merits of repricing (such as that discussed by Jin and Meulbroek at pp. 10-11), might well choose to follow the lead of other companies in choosing to reprice stock options.

${ }^{199}$ See BEBCHUK \& FRIED, supra note 2, at 137-85; Murphy, supra note 181, at 866.

${ }^{200}$ See Murphy, supra note 181 , at 866.

${ }^{201}$ See BEBCHUK \& FRIED, supra note 2, at 169-70 (discussing reload option); see also Murphy, supra note 181, at 866 (stating that the economic cost to companies granting options with reload provisions is high).

${ }^{202}$ See Lucian Bebchuk, Jesse Fried, \& David Walker, Managerial Power and Rent Extraction in the Design of Executive Compensation, 69 U. Chi. L. Rev. 751, n. 204 (2002) (citing proponents).

${ }^{203}$ See Charles M. Elson, The Duty of Care, Compensation, and Stock Ownership, 63 U. CIN. L. REV. 649, 690-92 (1995) [hereinafter "Elson I"] (suggesting that directors should be paid in restricted stock); see also Elson, supra note 66, at 981-83; Charles M. 
incentives with those of shareholders, with fewer attendant problems. ${ }^{204}$ Unlike options, restricted stock generally cannot be sold until the executive leaves the company. Executives paid in restricted stock therefore would not have an incentive to artificially inflate the share price over the short term, since they would not be able to cash in their stock until some time after they leave the company. ${ }^{205}$

BF respond that restricted stock suffers from the same windfall problems posed by stock options. Like stock options, restricted stock's value may rise because of causes entirely apart from the senior managers' efforts. ${ }^{206}$ Worse, restricted stock is like an option with an exercise price of zero. ${ }^{207}$ Restricted shares therefore increase the windfall problem posed by stock options. ${ }^{208}$

Some corporations have begun issuing restricted stock, however, in response to the increasing criticism of stock options. ${ }^{209}$ Although BF concede that restricted stock may possess one advantage over options executives' inability to sell their restricted shares and thereby eliminate the incentive to increase the stock price - they point out that options could also be so restricted. ${ }^{210}$ Indexed options with such restrictions on sale would possess all the benefits of restricted stock without the associated windfalls. Boards' nevertheless prefer to award restricted stock, indicating that some motive - such as capture - other than efficient compensation drives their decision. ${ }^{211}$

Elson, Director Compensation And The Management-Captured Board - The History Of A Symptom and a Cure, 50 S.M.U. L. REV. 127, 164-73 (1996) [hereinafter "Elson II"]; Murphy, supra note 110, at 738 ("[Restricted stock] continues to be one of the most effective vehicles for providing both incentives and compensation to managers.").

${ }^{204}$ See supra note 203.

${ }^{205}$ See Elson II, supra note 203, at 130-31; Elson I, supra note 203, at 985 ("To prevent the quick liquidation of these stock payments and consequent loss of equity-based incentive, the stock awarded must be restricted as to resale during the individual's directorship.").

${ }^{206}$ See BEBCHUK \& FRIED, supra note 2, at 170-73 (discussing restricted stock).

${ }^{207} I d$. at 171 .

${ }^{208} \mathrm{Id}$.

${ }^{209}$ Id. See also Joann S. Lublin, With Options Tainted, Companies Award Restricted Stock, Wall ST. J., March 3, 2003, at B1.

${ }^{210}$ See BEBCHUK \& FRIED, supra note 2, at 172.

${ }^{211} I d$. at 173 . 


\section{Group Dynamics Theory}

Restricted stock has a certain wholesome, emotional appeal. ${ }^{212}$ In contrast to options, which are relatively complicated and have recently become controversial, restricted stock seems soothingly simple. If boards want executives to share stockholders' incentives, the most straightforward thing to do is simply to make them stockholders. Restricting the stock's resale to ensure the executives remain shareholders is universally acknowledged as a positive aspect of this compensation method. ${ }^{213}$

Restricted stock may also allow directors to make positive use of the endowment effect. ${ }^{214}$ In contrast to options, which represent only contingent ownership, restricted stock awards grant executives immediate ownership of an equity interest in the firm. Executives may therefore experience a subsequent decline in stock price as a more tangible loss of wealth they actually owned, rather than merely the loss of the potential wealth generated by options. ${ }^{215}$

The appeal of restricted stock has long prompted scholars such as Charles Elson to advocate the use of restricted stock in compensation packages, at least for independent directors. ${ }^{216}$ A thorough analysis of the device might result, as BF contend, in a conclusion that restricted stock is inefficient and results in compensation that is poorly correlated to executives' performance. Nevertheless, the intuitive appeal of restricted stock, combined with significant support from scholars and other experts, may have sufficiently confused the issue to persuade a groupthink board of restricted stock's merits or to induce an uncertain board to turn to other corporations for guidance, resulting in a social cascade.

\footnotetext{
${ }^{212}$ Id. at 171 .

${ }^{213}$ Even BF seem to believe that the restriction on resale is a positive feature. See id. at 173.

${ }^{214}$ According to renowned expert Russell Korobkin, the endowment effect "stands for the principal that people tend to value goods more when they own them than when they do not." Russell Korobkin, The Endowment Effect And Legal Analysis, 97 Nw. U. L. REV. 1227, 1228 (2003).

${ }^{215} I d$. at $1250-55$ (explaining that the endowment effect is generally attributed to loss aversion, the notion that losses are perceived to be more serious than equivalent gains).

${ }^{216}$ See Elson, supra note 66, at 981-83 (advocating compensating outside directors with restricted stock); Elson, supra note 203, at 690-93 (same).
} 


\section{Freedom to Unwind Equity Incentives}

\section{Managerial Power Theory}

Corporations rarely impose limits on executives' ability to unwind the incentives produced by stock options. ${ }^{217}$ Senior managers generally remain free to exercise vested options and sell the resulting shares whenever the price seems advantageous. ${ }^{218}$ Not surprisingly, then, recipients exercise their options after an average of less than six years, and then sell roughly $90 \%$ of the shares gained. ${ }^{219}$ In addition, executives are almost always free effectively to cash in their options even before exercising them, by trading in derivatives. ${ }^{220}$ By using collars, ${ }^{221}$ for example, option-holders may essentially eliminate both the risk of the stock price sinking and the gain from any future rise, while simultaneously profiting from the difference between the options' exercise price and the current market price. ${ }^{222}$ The incentives created by stock options may therefore be even shorter-lived than first appears.

$\mathrm{BF}$ argue that boards' failure to restrict CEOs from undercutting the incentives options are designed to produce further supports their thesis that boards are captured. ${ }^{223}$ Directors who desired efficient compensation would be unlikely to spend enormous sums of the corporation's money to align executives' incentives with those of shareholders without ensuring that those incentives were reasonably durable. ${ }^{224}$ A captured board, however, might well justify large equity grants to the CEO and other senior officers by claiming that equity ownership would produce desirable incentives, without providing the necessary restrictions to preserve those incentives. ${ }^{225}$ Using unrestricted

${ }^{217}$ See BEBCHUK \& FRIED, supra note 2, at 174.

${ }^{218} \mathrm{Id}$. at 179.

${ }^{219}$ Id. at 176; Jennifer Carpenter, The Exercise and Valuation of Executive Stock Options, 48 J. OF FIN. ECON.. 127, 139 (1998).

${ }^{220}$ See BEBCHUK \& FRIED, supra note 2, at 176-77.

${ }^{221}$ A collar consists of buying a put option at the same time as selling a call option while owning a particular asset. See JOHn Hull, Options, FuturES AND OTHER DERIVATIVES $\left(6^{\text {th }}\right.$ ed. 2005).

${ }^{222} \mathrm{Id}$.

${ }^{223}$ See BEBCHUK \& FRIED, supra note 2, at 185.

${ }^{224} \mathrm{Id}$.

${ }^{225} \mathrm{Id}$. 
equity instead of cash provides the board with "camouflage" without imposing unacceptable risks of loss to senior management. ${ }^{226}$

\section{Group Dynamics Theory}

As BF acknowledge, restricting executives' ability to unwind the equity incentives provided by options and restricted stock would impose liquidity and diversification costs. ${ }^{227}$ Corporate officers subject to such restrictions would be unable to realize the value of their equity assets for long periods of time. If they discovered a better investment opportunity or needed money to spend on consumption, their options and restricted stock would be unavailable. Rational executives would therefore demand higher pay in compensation for the liquidity costs associated with limits on their ability to unwind equity incentives.

Also, restrictions would impede employees' efforts to diversify their investments, subjecting them to significant risks of financial losses. ${ }^{228}$ Executives whose portfolios consisted primarily or exclusively of equity in their employing corporation would likely prove risk averse in determining corporate actions. Finance theorists argue that diversified shareholders prefer corporations to pursue investments with the highest expected return, even if those opportunities are risky. ${ }^{229}$ But undiversified executives would generally have sharply different risk preferences. Equity restrictions might therefore actually increase agency costs.

The analysis of whether equity restrictions ultimately would increase or reduce total agency costs is complex and uncertain. I tend to agree with BF that restrictions on executives' ability to unwind equity incentives should prove efficient under at least some circumstances. ${ }^{230}$

\footnotetext{
${ }^{226} \mathrm{Id}$.

${ }^{227}$ Id. at 176; see also Brian Hall and Jeffrey B. Liebman, Are CEOs Really Paid Like Bureaucrats?, (March 1997), available at http://ssrn.com/abstract=2086 ("The data suggest that it could be very costly to firms to force CEOs to put a large fraction of their wealth at risk, since the firm would have to compensate the CEOs for taking such a risk.")

${ }^{228}$ See BEBCHUK \& FRIED, supra note 2, at 176.

${ }^{229}$ See Hall and Liebman, supra note 227, at 11 (arguing that equity restrictions "may induce risk-averse CEOs to avoid high-risk, high-return projects that are optimal from the perspective of well-diversified shareholders.")

${ }^{230}$ See BEBCHUK \& FRIED, supra note 2, at 178.
} 
But the issue is quite murky in most cases, creating a ripe situation for groupthink or a social cascade. ${ }^{231}$

\section{E. Retirement Pay}

\section{Managerial Power Theory}

Since the corporation bargains at arms-length with employees below the level of the senior management team, the arrangements made with these workers should be efficient. BF point out that corporations provide pension plans for lower-level employees only to the extent that the government subsidizes the plans with tax benefits. ${ }^{232}$ The plans set up for CEOs, in contrast, generally do not qualify for such favored tax treatment. Qualifying plans provide a deduction to the corporation but do not count as taxable income to the employee until the employee takes the money out of the plan. ${ }^{233}$ But these plans can only be based on compensation that does not exceed about $\$ 200,000 .{ }^{234}$ Because the retirement plans provided to CEOs (Supplemental Executive Retirement Plans ("SERPs")) are generally based on income that far exceeds this amount, corporations which grant them do not receive a deduction for the amount paid into the plan on the CEO's behalf, and also pay taxes on the investment income generated by the retirement funds. ${ }^{235}$

In addition, SERPs differ from the benefits provided to most other employees in that they are defined benefit - not defined contribution - plans. ${ }^{236}$ This change brings two consequences. First, the corporation bears the investment risk. Regardless of whether the funds set aside by the corporation are invested well or poorly, the corporation is obligated to provide a set benefit to the senior executive. ${ }^{237}$ Second, the investment income earned on the money provided is largely invisible

\footnotetext{
${ }^{231}$ See supra notes 102, 111 (discussing necessary conditions for a social cascade). I should note that BF's claim that executives exercise their freedom to unwind their equity incentives is strongly disputed. See John E. Core, Wayne R. Guay, and Randall S. Thomas, Is U.S. CEO Compensation Inefficient Pay Without Performance?, 103 MiCHIGAN L. REV. 1142, 1179-81 (2005).

${ }^{232}$ See BEBCHUK \& FRIED, supra note 2, at 95.

${ }^{233} \mathrm{Id}$. at $96-97$.

${ }^{234} I d$.

${ }^{235}$ Id. at $97-98$.

${ }^{236} \mathrm{Id}$. at $98-99$.

${ }^{237} \mathrm{Id}$.
} 
to shareholders. ${ }^{238}$ Under the current rules, corporations need not disclose on the executive income tables the increase in present value of the CEO's pension plan due to increasing years of service and/or increasing salary. ${ }^{239}$

$\mathrm{BF}$ thus argue quite strongly that the pension plans provided to CEOs and other senior executives are not efficient. These benefits differ sharply in several important respects from the analogous benefits provided to lower-level employees, are not linked to the performance of the executives who receive them, and are relatively difficult for shareholders or the financial press to evaluate in detail. ${ }^{240}$ Their widespread use by public corporations $\left(70 \%\right.$ in $\left.2002^{241}\right)$ despite these problems supports BF's theory that boards' primary goal in negotiating the CEO's compensation package is not efficiency, but maintaining the CEO's good will. ${ }^{242}$

In addition to SERPS, corporations also often offer senior executives the opportunity to defer some portion of their compensation. $^{243}$ This arrangement is highly beneficial to the participating executives, because they do not pay taxes on deferred income until they actually receive it. ${ }^{244}$ In addition, while the corporation retains the money, the executives receive interest income often above market rates - which is also tax-free until actually paid

\footnotetext{
${ }^{238}$ See Lucian Bebchuk and Jesse Fried, Executive Compensation as an Agency Problem, 17 J. ECON. PERSP. 71 (2003) ("Among the arrangements used by firms that camouflage the amount and the performance-insensitivity of compensation are pension plans, deferred compensation, and post-retirement perks and consulting contracts."); see also, Kevin Murphy, Executive Compensation, at 23-24 (June 1999), in ORLEY ASHENFELTER AND DAVID CARD (EDS.), HANDBOOK OF LABOR ECONOMICS, Vol. 3, North Holland (1999), available at http://www-rcf.usc.edu/ kjmurphy/ceopay.pdf (explaining why some have called SERPs "the ultimate form of 'stealth compensation."').

${ }^{239}$ See BEBCHUK \& FRIED, supra note 2, at 99-100. The SEC's Proposed Rule 2.B.1.d.ii regarding disclosure of executive compensation, if passed, may effectively change this result by requiring disclosure of the amount each covered officer would likely receive in annual retirement benefits once that officer became eligible for retirement. See 71 FED. REG. 6542, 6561 (2006), also available at http://sec.gov/rules/proposed/2006/33-8655fr.pdf.

${ }^{240}$ See BEBCHUK \& FRIED, supra note 2, at 96-99.

${ }^{241}$ Id. at 98 .

${ }^{242} I d$. at $95-102$.

${ }^{243} \mathrm{Id}$. at $102-03$.

${ }^{244} \mathrm{Id}$. at 102.
} 
out. $^{245}$ If instead the executives had taken their full salaries and invested their earnings themselves, they would (a) pay income taxes on the salary earned, and therefore invest a smaller amount, and (b) pay income taxes on the investment income earned on the money. ${ }^{246}$ Deferred compensation plans are therefore enormously beneficial to executives permitted to participate.

From the corporation's perspective, these arrangements have a very different complexion. By deferring some of an executive's salary, the corporation loses the tax deduction that it would have accrued. ${ }^{247}$ The corporation also pays taxes on the income it earns by investing the money on the executive's behalf. ${ }^{248}$ The corporation does not receive a tax deduction until it actually pays the executive, generally many years later. $^{249}$

These arrangements might be efficient if a corporation either paid taxes at a lower rate than an individual executive, or had access to abovemarket returns on investment. ${ }^{250} \mathrm{BF}$ correctly point out, however, that corporations generally pay much higher taxes than individuals on longterm capital gains. ${ }^{251}$ Also, corporations with ready access to capital through the financial markets are unlikely to have above-market returns to offer to executive "lenders." 252 If they did, they would borrow money from the markets at the market rate and invest it at above-market rates. There would be no need to pay executives abnormally high returns to garner this opportunity.

Additional, though indirect, evidence of this arrangement's inefficiency comes from an examination of the benefits offered to lowerlevel employees. These workers are not generally provided an opportunity to defer compensation, unless the deferral is tax efficient, such as through the use of a $401(\mathrm{k})$ plan. $^{253}$ Once the comparatively low limits imposed on such plans are exceeded, corporations seldom offer

\footnotetext{
${ }^{245} \mathrm{Id}$. at $102-03$.

${ }^{246} I d$. at 104 .

${ }^{247} \mathrm{Id}$.

${ }^{248} \mathrm{Id}$.

${ }^{249} \mathrm{Id}$.

${ }^{250} \mathrm{Id}$.

${ }^{251} \mathrm{Id}$.

${ }^{252} \mathrm{Id}$

${ }^{253}$ Id. at 103 .
} 
employees the type of deferred compensation benefit frequently offered to senior executives. ${ }^{254}$

If deferred compensation arrangements are inefficient, why do profit-driven corporations use them? BF cogently argue that these plans offer captive boards an opportunity to divert extra income to senior executives without bearing outrage costs. ${ }^{255}$ Deferred compensation plans are easily camouflaged. Although the amount deferred must be disclosed in the SEC compensation tables, the investment return corporations pay executives on this amount does not, unless it exceeds $120 \%$ of the federal rate at the time the corporation establishes the rate of return. ${ }^{256}$ This rule allows corporations to increase the guaranteed rate of return when interests rates rise without disclosure. ${ }^{257}$ At the same time, firms may freely maintain previous high rates of return without disclosure when the market rate declines. ${ }^{258}$

\section{Group Dynamics Theory}

Retirement pay and deferred compensation can be justified as the low-risk component of executive compensation. Although BF argue that pay should be closely tied to performance to maximize executives' incentives to excel, not all pay can be performance-related. ${ }^{259}$ Even in undisputedly arms-length employment relationships, much of employees' pay comes in risk-free forms such as guaranteed salary and retirement benefits. These compensation forms are uncontroversial when used to reward employees who are lower in the pecking order and therefore impose lower agency costs. Performance pay is arguably more important, however, for corporate officers less subject to supervision, such as CEOs. Even for these officers, though, some portion of guaranteed pay is likely to prove efficient. Most people are risk-averse in regard to loss, at least to some degree, and corporate officers are no

\footnotetext{
${ }^{254} \mathrm{Id}$. at. 105 .

${ }^{255} \mathrm{Id}$. at $105-07$.

${ }^{256} \mathrm{Id}$. at 106 .

257 Id.

${ }^{258} I d$.

${ }^{259}$ Id. at 19 ("Economists have long believed that efficient compensation contracts should link pay with performance to provide executives with desirable incentives.")
} 
exception. ${ }^{260}$ CEOs asked to forego any form of guaranteed pay are therefore likely to insist on much higher expected compensation to offset the risk of receiving nothing at all. Some blend of guaranteed and performance-linked pay is likely the most efficient outcome in most cases.

Although these forms of compensation may be acceptable, BF appear to argue that the amounts that are awarded through these methods are not. When corporations award lower-level employees retirement pay or deferred compensation, they provide only as much as receives a tax subsidy. ${ }^{261}$ Executives, in contrast, receive much more. BF argue perhaps correctly - that this dichotomy demonstrates that retirement pay and deferred compensation are not efficient, presumably because employees value other forms of guaranteed pay (such as salaries) more than retirement benefits.

But again, the issues involved are complex and not easy to resolve conclusively. Even $\mathrm{BF}$ do not advance direct evidence that retirement pay is inefficient for all CEOs. Executives, much of whose pay is dependent on the corporation's performance and/or its stock price, may value retirement pay's security more than lower-level employees, most of whose compensation comes in a guaranteed salary. The analysis is sufficiently complex that a strong CEO may persuade a consensusdriven board to adopt a favorable retirement package. Alternatively, in the presence of this uncertainty, a social cascade may arise in which boards follow the first few movers and disregard their own private information.

\section{F. Company Loans}

\section{Managerial Power Theory}

BF remind us that prior to Sarbanes-Oxley, public corporations frequently loaned large sums of money to their officers and directors at below-market interest rates. ${ }^{262}$ These loans were generally either unsecured or secured only by corporate stock, and firms often committed

\footnotetext{
${ }^{260}$ See Cass Sunstein, Moral Heuristics and Moral Framing, 88 MinN.. L. REV. 1556, 1591 (2004) ("[P] $]$ eople are risk-averse with respect to gains, but risk-seeking with respect to losses ....").

${ }^{261}$ See BEBCHUK \& FRIED, supra note 2, at 95.

${ }^{262} I d$. at 112.
} 
to forgiving the loans entirely if the recipient remained at the company for a set number of years. ${ }^{263}$

A corporation could set up a system of loans that would encourage performance. For example, a company might agree to forgive portions of the loan as the executive achieved certain performance targets. Alternatively, the firm might loan an executive money for the sole purpose of purchasing corporate stock, thereby better aligning the executive's interests with those of shareholders. The loans actually made, however, did not include such features. Loan forgiveness was tied, not to performance, but to tenure, rewarding executives simply for staying regardless of what they achieved. ${ }^{264}$ And although $40 \%$ of corporate loans made in 2002 helped executives buy company stock, the lending firms did not restrict executives' ability to sell shares they already owned at the same time they were purchasing new shares with the loaned funds. ${ }^{265}$ As a result, the recipients of such loans on net used an average of only $8 \%$ of the money loaned to increase their share ownership. ${ }^{266}$

According to BF, boards utilized corporate loans as a means of enriching executives while avoiding outrage costs. ${ }^{267}$ Although when loans were permitted, the SEC required disclosure of the interest rate subsidy (the extent to which the market rate exceeded the loan's rate), $\mathrm{BF}$ argue that the definition of this term was ambiguous, permitting many corporations to avoid this disclosure requirement. ${ }^{268}$ In addition, BF point out, the amount loaned did not count as compensation unless and until the debt was forgiven. ${ }^{269}$ As such, companies could delay the disclosure of this form of compensation for many years. ${ }^{270}$ Corporate loans therefore provide additional, though historic, evidence that boards grant senior executives performance insensitive compensation in ways that are difficult for investors to detect. ${ }^{271}$

\footnotetext{
${ }^{263} \mathrm{Id}$.

${ }^{264} \mathrm{Id}$. at $112-14$.

${ }^{265} \mathrm{Id}$. at 114.

${ }^{266} \mathrm{Id}$. at $114-15$.

${ }^{267} \mathrm{Id}$. at $115-17$.

${ }^{268} \mathrm{Id}$. at 115 .

${ }^{269} I d$. at 116.

${ }^{270} \mathrm{Id}$.

${ }^{271} \mathrm{Id}$. at $112-17$.
} 


\section{Group Dynamics Theory}

Before Sarbanes-Oxley, CEOs could easily defend the common practice of making loans to executives as an efficient form of compensation that took advantage of the psychological phenomenon known as the endowment effect. The endowment effect is produced by loss aversion, the observation that people dislike losses more than they appreciate gains. $^{272}$ That is, as Tversky and Kahneman have explained, "[T] he loss of utility associated with giving up a valued good is greater than the utility gain associated with receiving it." ${ }^{273}$ As a result, people value things more once they own them.

A famous classroom experiment conducted by Kahneman, Knetsch and Thaler illustrates this proposition nicely. ${ }^{274}$ The authors provided one-third of the students with a coffee mug whose retail value was around $\$ 5 .{ }^{275}$ These students were then asked to value the mug. ${ }^{276}$ The remaining students were told that they had a choice between a coffee mug and an amount of money, and were asked a series of questions designed to find out the point at which the students would choose the money over the mug. ${ }^{277}$ The first group of students, who were given a mug at the beginning, evaluated the sale of the mug as a loss of something they owned. ${ }^{278}$ The remaining students, who began the experiment with nothing, perceived the mug as a possible gain. ${ }^{279}$ As the endowment effect predicts, the students who already owned the mug valued it about twice as highly as those students who began in a neutral position. ${ }^{280}$

The endowment effect teaches us that people are more reluctant to give something up than they are eager to gain it to begin with. Corporate loans may have taken advantage of this phenomenon to

\footnotetext{
${ }^{272}$ See Amos Tversky \& Daniel Kahneman, Loss Aversion in Riskless Choice: A Reference-Dependent Model, 106 QUARTERLY J. ECON. 1039, 1040-44 (1991) (discussing experiments that have validated the endowment effect, a result of loss aversion).

${ }^{273}$ Id. at 1041 .

${ }^{274} I d$. .

${ }^{275} \mathrm{Id}$.

${ }^{276} \mathrm{Id}$

${ }^{277}$ Id.

${ }^{278} I d$.

${ }^{279} I d$.

${ }^{280} I d$.
} 
produce greater incentives. The loans were ultimately forgiven if the employee remained with the company the requisite number of years. ${ }^{281}$ As a result, the loans plus forgiveness were effectively the equivalent of a cash bonus for each year of employment, with one important difference: the executives received the full amount of the loan in the first year. Under the endowment effect, once the employees received the loan proceeds, they would value the amount more than if they were promised that amount for staying with the company in the future. The threatened loss of the already-received retention bonus may have produced a stronger deterrent to premature departures than would a promised retention bonus. This point is debatable, and depends on a number of factors. For example, in many circumstances, the expenses to the corporation associated with having to pay the money up front (from loss of liquidity or because the loan was granted with below-market interest) may have outweighed any benefit from the endowment effect. But the arguments are sufficiently complex and uncertain to open the door to the impact of groupthink and social cascades.

\section{G. Soft Landings for Failures}

\section{Managerial Power Theory}

Chief executives typically receive significant downside protection as part of their employment contracts. In sharp contrast to most employees, who can be fired at the will of their employers, CEOs can usually be terminated only for "cause," where "cause" is defined very narrowly to include only the most extreme bad behavior. ${ }^{282}$ In the unlikely even that the board does fire a CEO, the CEO's employment contract generally calls for several years' compensation as a severance payment. $^{283}$ This multi-year period far exceeds the compensation typically granted to other employees and may approach the length of the underlying contract. ${ }^{284}$ If these arrangements are efficient, BF argue, then they should be granted to all employees. ${ }^{285}$ The reality that only

\footnotetext{
${ }^{281}$ See BEBCHUK \& FRIED, supra note 2, at 116-17.

${ }^{282} \mathrm{Id}$., at 133 (listing commission of a felony, fraud, gross negligence, and refusal to follow board direction as some of the few actions that could constitute "cause" in a typical CEO employment contract).

${ }^{283} \mathrm{Id}$.

${ }^{284} I d$. at 134

${ }^{285} I d$.
} 
senior officers receive such terms supports the argument that executive compensation is the result of captured boards and not an efficient market.

\section{Group Dynamics Theory}

While BF convincingly make the point that CEOs receive unusually favorable severance arrangements, this by itself does little to support their thesis that management has captured most public company boards. Boards might grant such generous severance terms for the same reason that courts have conferred on senior management similarly generous protection from liability - the need for CEOs to take substantial risks. $^{286}$ One of the bedrock principles of corporate finance is that shareholders want their corporations to invest in the projects with the highest expected returns, even if those projects also carry a great deal of risk. $^{287}$ Because shareholders have diversified their investments, on average they will earn a greater return if each corporation pursues the possibilities with the highest potential yields. Even though some of these investments will fail, those that succeed will more than make up for the loss. $^{288}$

Although risk-taking benefits shareholders, CEOs may prove risk-averse. The CEO of a corporation whose high-risk, high-reward investment fails can take little consolation in the success of other corporations who pursue a similar strategy. That CEO is likely to lose

\footnotetext{
${ }^{286}$ Delaware courts review actions by the board of directors and senior officers under the highly deferential business judgment rule. As the Delaware Supreme Court has stated:

The business judgment rule exists to protect and promote the full and free exercise of the managerial power granted to Delaware directors. The rule itself "is a presumption that in making a business decision, the directors of a corporation acted on an informed basis, in good faith and in the honest belief that the action taken was in the best interests of the company." Thus, the party attacking a board decision as uninformed must rebut the presumption that its business judgment was an informed one. Smith v. Van Gorkom, 488 A.2d 858, 872 (Del. 1985) (internal citations omitted).

${ }^{287}$ See supra note 229.

${ }^{288}$ See Peter V. Letsou, Implications of Shareholder Diversification on Corporate Law and Organization: The Case of the Business Judgment Rule, 77 CHI.-KENT L. REV. 179, 184-95 (2001) (explaining portfolio theory).
} 
his or her job, perhaps because of the board's hindsight bias ${ }^{289}$ or perhaps because the company itself becomes insolvent when the risk materializes. Either way, a CEO strictly pursuing self-interest will likely take fewer risks than the company's shareholders would like. In order to induce the CEO to take more risks, the board may rationally offer, in advance, extremely generous downside protection. Lower-level employees, in contrast, serve under the CEO's direction. They implement the CEO's decisions, but do not generally make strategic decisions. As a result, lower-level corporate employees do not needand unsurprisingly rarely receive - the extensive protection granted to the CEO.

A CEO who knows in advance that he or she will be generously compensated even for failure may feel more comfortable taking the highrisk actions the company's shareholders desire. This argument does not apply to "gratuitous" post-termination payments, those made without a preexisting contractual obligation, since the compensation can only motivate CEOs who know in advance they will receive it. But the sort of contract-based severance payments BF complain of may well be a perfectly rational inducement to risk-taking. At a minimum, these arrangements are sufficiently defensible to pass muster for a groupthink board, or one subject to a social cascade.

\section{$\underline{\text { H. Gratuitous Payments }}$}

\section{Managerial Power Theory}

BF describe three types of payments boards commonly award to CEOs that appear gratuitous, that is, that the CEO's employment contract does not require. ${ }^{290}$ These payments support BF's theory, they contend, because a board bargaining at arms-length has no reason to give what is essentially a gift of additional compensation. ${ }^{291}$ These payments are different from bonus plans, which provide by contract for additional payments triggered by meeting certain performance goals. ${ }^{292}$ The

\footnotetext{
${ }^{289}$ Hindsight bias refers to people's tendency to overestimate the odds of an event occurring ex ante once they know that the event did actually occur. See Christine Jolls \& Cass Sunstein, Debiasing Through Law, 35 J. LeGAL STUD. 199, 204 (2006).

${ }^{290}$ See BEBCHUK \& FRIED, supra note 2, at 87-94.

${ }^{291} I d$. at 94.

${ }^{292}$ Id. at 87.
} 
gratuitous payments BF discuss represent compensation over and above the bonus payments required by the CEO's employment contract.

The first type of gratuitous payment BF document comes when CEOs are terminated. ${ }^{293}$ Boards dealing with their CEOs at arms-length should have no reason to offer extra compensation to CEOs whose poor performance motivates the board to fire them. Yet BF assert that boards often make such payments, over and above any severance pay required by the CEO's employment contract. ${ }^{294}$

At first glance, such payments seem as baffling to managerial power theorists as they do to scholars who believe boards bargain with CEOs over their pay at arms-length. A captive board would seem incapable of firing its captor, the CEO ${ }^{295}$ Yet if a board did escape its bonds, why would it desire to shower the deposed executive with gifts?

$\mathrm{BF}$ explain that boards grant gratuitous compensation to CEOs after firing them for two reasons. First, far from escaping the CEO's influence, the board feels the need to bribe the CEO to leave. ${ }^{296}$ Under BF's theory, boards escape the CEO's influence sufficiently to ask for the chief executive's departure, but not to demand it. ${ }^{297}$ Second, the directors pay the terminated CEO to signal CEOs of other companies that they are not threatening, that they can be trusted to look after CEOs' interests and should therefore be selected as directors of other corporations. $^{298}$ Managerial Power therefore seems capable of explaining a phenomenon that Optimal Contracting cannot.

Boards give CEOs the second type of gratuitous payment when their corporations are acquired. ${ }^{299}$ BF write that $27 \%$ of target boards grant their CEO a gratuitous bonus once the takeover is approved. ${ }^{300}$ From an arms-length contracting perspective, it is difficult to understand why an independent board would pay the CEO a bonus under these

\footnotetext{
${ }^{293}$ Id. at $88-89$.

${ }^{294}$ Id.

${ }^{295}$ BF explain terminations as resulting from outrage costs exceeding some level. Id. at 88.

${ }^{296} \mathrm{Id}$. at 89.

${ }^{297}$ This theory is less troubling than it might at first appear. Although the board as a whole may be captive, presumably some directors would be more firmly influenced than others. A divided board might well recognize that a CEO had performed so poorly that termination was necessary, yet prove unable to muster a majority to support replacement without the CEO's acquiescence.

${ }^{298}$ See BEBCHUK \& FRIED, supra note 2, at 89.

${ }^{299} \mathrm{Id}$. at $89-91$.

${ }^{300}$ Id. at 90.
} 
circumstances. The CEO may or may not go on to work for the acquirer, but in neither case does this type of reward appear to benefit the target's shareholders. The board should pay the CEO only in order to induce better performance. While the promise of a bonus might induce the CEO to try harder to get the best possible price for the target's shareholders, any additional, surprise, payments cannot possibly have any effect on the CEO's behavior. The best argument Optimal Contracting adherents might make to explain this behavior is that since corporations have awarded such bonuses in the past, a CEO may anticipate this sort of reward for particularly hard work. But presumably whatever effect a hoped for bonus might have would be much weaker than the motivation produced by a firm promise of a large reward for excellent results. Boards' frequent - though hardly universal - awarding of bonuses without an advance promise makes little sense if we start from the assumption that boards act strictly in shareholders' interests.

BF conclude, perhaps a bit too quickly, that this behavior makes much better sense when one understands that CEOs have captured their directors. ${ }^{301}$ Boards grant CEOs these payments because CEOs ask for them, and perhaps because the directors feel uncomfortable that by agreeing to be acquired they are removing the CEO from power. ${ }^{302}$

If CEOs' power over the directors is rooted in their ability to grant board seats to the directors, though, it is difficult to understand why the board would offer additional payments at the very moment that power is terminated. As BF themselves state, the target's directors usually lose their positions when the company is purchased. ${ }^{303}$ Why, then, would the target's CEO retain any influence over the board, when the directors have no realistic hope of any continuing reward?

The answer may lie in the board's need to persuade the CEO to consent to the acquisition in the first place. ${ }^{304} \mathrm{BF}$ point out that acquirers often pay CEOs - either in cash or with a position in the company - in order to persuade the CEO to agree to the deal. ${ }^{305}$ Although BF do not seem to make this argument explicitly, if acquirers feel the need to placate the CEO to allow the transaction to proceed, perhaps targets' boards feel the same way.

\footnotetext{
${ }^{301} I d$. at 90 .

${ }^{302} I d$.

${ }^{303} I d$.

${ }^{304} I d$.

${ }^{305}$ Id. at $91-92$.
} 
This explanation may prove susceptible to the same dilemma surrounding termination payments: if the board is captive, how can it agree to the acquisition in the first place, much less negotiate the CEO's bribe? In this context, though, the problem seems more tractable. While a CEO may be very reluctant to be fired, regardless of the size of the resulting severance payment, a chief executive may be far more willing to permit the company's sale at a premium.

Unlike a termination, which carries an unavoidable taint of failure and is very likely to damage the CEO's reputation, the corporation's sale at a premium can signal a remarkable success. A CEO may therefore be not only willing but perhaps even eager to sell the company, provided sufficient compensation is offered for the lost position. The captured board would then be left only with the role of agreeing to whatever payment the CEO demanded in exchange for permission to sell the company. Managerial Power therefore offers a potential explanation for this phenomenon that is not easily explained by Optimal Contracting.

The third category of gratuitous compensation cited by BF in support of their theory is retirement payments beyond those provided by the CEO's employment contract. ${ }^{306} \mathrm{BF}$ contend that corporations commonly provide extra-contractual retirement benefits to CEOs, generally making these arrangements at or very near the time the CEO retires. ${ }^{307}$ The authors point out that while the possibility of receiving these extra payments might induce a CEO to work harder during his or her tenure, well-designed option or bonus plans would likely fulfill this function more efficiently. ${ }^{308}$ CEOs can be expected to work harder for benefits the board contractually binds itself to award in exchange for excellent performance than for benefits the CEOs only hope the board will award them.

Managerial Power, on the other hand, explains that captured boards see the CEO's retirement as one last opportunity to express their appreciation for the CEO's largesse. Also, these benefits offer the additional advantage of being much less noticeable than cash payments such as salary and bonuses. Under the current SEC disclosure rules, only the formula for calculating these benefits - not their cash value - must be

\footnotetext{
${ }^{306} I d$. at 92-93.

${ }^{307} \mathrm{Id}$. at 92.

${ }^{308}$ Id. at 93.
} 
disclosed, and even this disclosure is omitted from the compensation tables where most of the CEO's compensation is presented. ${ }^{309}$

BF do not explain, however, why a captured board would continue to obey a CEO who is about to retire. As I argued above in discussing acquisition payments, ${ }^{310}$ if the board's capture is rooted in self-interest and the CEO's power over the director nomination process, the point of the CEO's departure ought to also signal the end of the CEO's power over the board. The board's continuing fidelity at this juncture must find its explanation elsewhere. BF themselves seem to acknowledge this point, by arguing that the payments in part stem from the board's gratitude for past service and feelings of collegiality, rather than pure self-interest. ${ }^{311}$ This sort of emotional response by the directors, though, cannot fairly be described as managerial "power" derived from the CEO's ability to grant a board seat.

\section{Group Dynamics Theory}

Managerial Power's explanation of gratuitous payments seems troubling. BF argue that corporations make gratuitous payments on three occasions: when the board fires the CEO, when the corporation is acquired, and when the CEO retires. ${ }^{312}$ Under all three circumstances, the board is rewarding the CEO just as the CEO's power over them is ending. Once the CEO has been fired, or the company has been bought out, or the CEO has retired, the CEO will cease to have any influence over appointments to the board of directors.

BF's explanation of this anomaly - that the board must bribe the CEO to relinquish power - seems logically problematic, based on their premises. If CEOs' power stems from their ability to control appointments to the board, then why should a board that is about to fire its $\mathrm{CEO}$ - in the teeth of this power - grant the CEO a parting gift? Is it really credible that the board needs to bribe the CEO to accept being

\footnotetext{
${ }^{309} \mathrm{Id}$. Note that the new rules proposed by the SEC would change this result by requiring disclosure of the increase in actuarial value in the year reported of any defined-benefit pension plan under the "All Other Compensation" column of the compensation tables. This figure would also contribute to the tables" "Total" column. See 71 FED. REG. 6542, 6552 (2006), also available at $\mathrm{http} / / / \mathrm{sec}$. gov/rules/proposed/2006/33-8655fr.pdf.

${ }^{310}$ See supra notes 303-305 and surrounding text.

${ }^{311}$ See BEBCHUK \& FRIED, supra note 2, at.93.

${ }^{312} \mathrm{Id}$. at $87-94$.
} 
fired? CEOs who have the power to prevent their termination would presumably prefer to keep their jobs rather than accept a bribe to leave. Otherwise, they would retire, not be fired. Similarly, in the takeover context, once the company has been purchased, the CEO's power to appoint directors will end. Knowing this, the directors should feel free to vote against the CEO's wishes in accepting a takeover bid, since the vote itself will eliminate the CEO's ability to retaliate against them. There should therefore be no need to bribe the CEO to permit the board to act as it pleases in response to an offer to purchase the company. This explanation works somewhat better, though, when we consider that takeover golden handshakes are often paid by the purchasing corporation. $^{313}$ If the payment is the acquirer's bribe and not the board's, the theory holds together much better. Then the payment is merely a recognition by the acquirer that the board is under the CEO's thumb, and that gaining the CEO's acquiescence is a necessary prerequisite to a friendly acquisition. The bribery story has the most explanatory power in the retirement context, where the CEO is free to continue to work if the board refuses to grant the bribe, and would then remain in a position to replace the directors.

The alternative explanation - that directors grant parting gifts to CEOs in order to signal their acceptability to other CEOs - also has difficulty explaining post-termination and takeover payments. Under Managerial Power's analysis, CEOs want the most docile directors they can find. ${ }^{314}$ Directors who fire their CEO - even if they then pay the departing CEO a great deal of money - can hardly expect to make the top of anyone's appointments list. They have demonstrated a capacity for regicide and are therefore tainted. Golden handshakes may dissipate the taint to some degree, but surely the pool of board candidates offers plenty of potential directors with no taint at all. In the takeover context, the CEO the directors should be most eager to please is the chief executive of the purchasing entity. That person can hardly expect to rejoice that some of the target's capital is leaking out just before the deal is consummated. Perhaps CEOs of other companies will be reassured,

\footnotetext{
${ }^{313} I d$. at 91-92 (discussing acquirer-paid "sweeteners").

${ }^{314}$ As Warren Buffet has gibed about compensation committees in particular, "There is a tendency to put cocker spaniels on compensation committees, not Doberman pinschers." Keith Naughton et al., The Perk Wars: As Jack Welch's Retirement Deal Sparks an Investor Backlash, Perks Could Become the New Stock Options, NEWSWEEK, Sept. 30, 2002, at 44.
} 
but again, these directors have shown that they will vote for an acquisition that displaces their CEO. More obedient directors can no doubt be found. The signal theory, like the bribery thesis, makes most sense when applied to CEO retirements. The replacement CEO may take some comfort from knowing that the board is reliably generous, and may choose to keep the directors on for that reason.

In all three contexts, groupthink - though not social cascades may offer a better explanation. Gratuitous payments are unlikely to be the result of a social cascade because there is there is little mystery about their inefficiency. Board members therefore do not lack sufficient information to evaluate them.

Groupthink, however, may provide a reasonable explanation for at least some of these payments. Boards subject to groupthink are accustomed to following the CEO's lead without much question. The essence of groupthink is the refusal to consider conflicting arguments or evidence once the majority or the group leader has adopted a position. ${ }^{315}$ Groupthink boards may therefore be highly susceptible to the suggestion that they should pay the CEO a bonus as a parting gift for a job well done when the CEO retires or the company is acquired, even if the CEO actually performed poorly. This rationale is common in other familiar contexts, such as tipping in a restaurant in a strange city, and may therefore pass without much comment. Although an outside, independent analysis would indicate that payments initiated after the CEO's departure cannot motivate better performance, it is the nature of groups subject to groupthink that they do not perform such analyses. ${ }^{316}$ In addition, as with Managerial Power, to the extent that takeover payments come from the acquirer, and not the target's board, they may be explained as stemming from the buyer's recognition that the CEO is the board's leader. Motivating the group leader to favor the offer is surely likely to improve the bidder's chances.

Groupthink's explanation of post-termination bonuses is a bit more involved. Although a board that fires its CEO may remain subject to groupthink, in the sense that its members may still self-censor dissenting voices, its leadership will necessarily move away from the CEO. CEOs cannot be expected to lead the board to their own termination. To explain why a groupthink board would choose to fire its $\mathrm{CEO}$ but also award the CEO a post-termination payment requires an

\footnotetext{
${ }^{315}$ See supra Part IIA.

${ }^{316}$ See supra notes 48-49.
} 
understanding of where leadership is likely to shift. One possibility is that the new leader is the incoming CEO. If so, the new chief executive may want to set a precedent that even failed CEOs should be awarded lucrative parting bonuses. It is more likely, though, that at least for a time, leadership will shift to the board member or members who led the effort to oust the CEO. Since most board members are current, former, or hopeful future CEOs of other companies, they too may like the idea of setting a generous precedent.

\section{$\underline{\text { I. Direct Evidence of Power's Impact }}$}

The bulk of BF's book is devoted to discussing indirect evidence of boards' capture. The heart of their argument is that the compensation methods in common use are far too inefficient to support the theory that boards are independent. ${ }^{317}$ Directors with the corporation's interest at heart would use better devices, such as indexed options, that linked executives' pay more closely to their performance. ${ }^{318}$ The preceding subsections have discussed the bulk of this evidence, as well as Group Dynamics Theory's alternative explanation for the observed corporate behavior.

But BF also provide somewhat more direct evidence that boards are captured. ${ }^{319}$ They posit that certain factors seem likely to make boards weaker and CEOs commensurately stronger. ${ }^{320}$ Some examples include the presence of antitakeover measures, such as poison pills; the absence or relative scarcity of large shareholders; interlocking directors, when one or more directors of one corporation also sit on the board of another corporation; boards that are relatively large; CEOs that also serve as chair of the board; and boards that have been appointed while the current CEO was in office. ${ }^{321}$ These factors correlate with higher CEO compensation, suggesting that managerial power can produce excessive compensation, perhaps through directorial capture. ${ }^{322}$

\footnotetext{
${ }^{317}$ See BEBCHUK \& FRIED, supra note 2, at 87-185 (cataloguing the inefficient forms of compensation in common use).

${ }^{318}$ Id. at $140-46$.

${ }^{319} \mathrm{Id}$. at $80-86$.

${ }^{320} \mathrm{Id}$. at $80-84$.

${ }^{321}$ Id.

${ }^{322}$ Id.
} 
My own work supports the notion that managerial power can result in excessive compensation. ${ }^{323}$ Effects can have more than one contributing cause, however. BF argue powerfully that executive pay in public corporations is structured poorly, and that managerial power over boards seems to intensify the use of inefficient compensation devices. Yet, as Steven Bainbridge has pointed out, even corporations with boards that appear relatively independent by conventional direct measures such as those with one or more shareholders who own large blocks of stock. - still employ the same inefficient compensation methods. ${ }^{324}$ Admittedly, none of BF's independence factors directly measures board autonomy. For example, institutional shareholders, who may own large blocks of a company's stock, may not choose to exercise their influence, for a variety of reasons. ${ }^{325}$ Nevertheless, some public company boards must be more independent than others, yet nearly all public companies draw from the same pool of inefficient compensation structures. ${ }^{326}$ How can BF explain the prevalence of inefficient compensation even in corporations that enjoy a relative absence of managerial power?

Two additional points trouble me about BF's account of corporate governance that do not appear to have drawn critics' attention. First, BF's theory depends on directors' willingness to sell their integrity for the price of a board seat. Yet, as BF themselves point out, most board members are richly-paid executives of other companies. ${ }^{327}$ Why would managers earning millions or tens of millions of dollars a year feel compelled to take any action for the relatively paltry sum in the range of a hundred thousand dollars? CEOs' power over their boards seems fairly

\footnotetext{
${ }^{323}$ See Dorff, supra note 3, at 277-83 (presenting the results of an empirical test of power's impact on executive compensation).

${ }^{324}$ See Stephen M. Bainbridge, Executive Compensation: Who Decides?, 83 TEX. L. REV. 1615, 1628-29 (2005).

${ }^{325}$ See Dorff, supra note 2, at 834-37 (explaining that institutional investors often face conflicts of interest that prevent them from monitoring corporations effectively and that popular investment strategies such as indexing sap institutional investors' incentives to allocate resources to monitoring corporate governance).

${ }^{326}$ For example, stock options achieved nearly universal use among public companies during the 1990s. See Eli Ofek \& David Yermack, Taking Stock: Equity-Based Compensation and the Evolution of Managerial Ownership, 55 J. FIN. 1367, 1367 (2000) (stating that in 1997, the 200 largest companies had reserved more than 13\% of their common shares to be used to compensate their managers).

${ }^{327}$ See Bebchuk \& Fried, supra note 2, at 33 (41\% of directors on compensation committees were executives in 2002, with an additional $26 \%$ retired former executives). See also Dorff, supra note 2, at 845.
} 
weak if the only consequence of a director's defiance is losing a position that accounts for an insignificant percentage of the director's total income. BF argue that directorships are also very prestigious, but CEOs of public companies already occupy positions that are more prestigious than directorships.

Second, as behavioral economists have proven repeatedly, people are not pure rational actors who successfully maximize their individual utility. ${ }^{328}$ On the contrary, humans are subject to many consistent biases that interfere with their ability to achieve or even determine their most favored outcomes. ${ }^{329}$ Cultural and social influences also cause us to take actions that are not in our narrow self-interest, such as giving anonymous donations to charity. Compounding these characteristics of individual decision-making are group decision-making phenomena that play an analogous role in collective decisions, as I have discussed at length above. ${ }^{330}$ Yet BF's discussion of boards' behavior largely ignores these insights in favor of an implicit model that seems to assume that groups will behave just like individuals, and that individuals always act in their financial best interest. ${ }^{331}$ A more complete account of boards' behavior must also take into account the difference between individual and group decision-making, as I attempt to do in this Article.

\section{Exploring Solutions}

So far, I have argued that Group Dynamics Theory may explain, either fully or partially, the executive compensation inefficiencies BF have identified. In this section, I will briefly outline the type of solution that should be pursued to the problems unveiled by Group Dynamics Theory.

${ }^{328}$ The classic review of this literature is Christine Jolls, et al., A Behavioral Approach to Law and Economics, 50 STAN. L. REV. 1471 (1998) (discussing the literature demonstrating flaws in the rational actor model of human behavior).

${ }^{329} \mathrm{Id}$. Examples include the hindsight bias, the endowment effect, optimism bias, the availability heuristic, etc.).

${ }^{330}$ See infra Part II (describing groupthink and social cascades).

${ }^{331} \mathrm{BF}$ do briefly describe the possible impact of individual psychological factors, but this discussion seems limited to the possibility that such factors might reinforce the preexisting power dynamic. See Bebchuk \& Fried, supra note 2, at 31-34. They also consider the possible effect of norms and mistakes. Id. at 74-79. BF never discuss social and psychological factors as an alternative root cause for the behavior they observe, nor do they ever consider group dynamic phenomena such as those I discuss here. 
$\mathrm{BF}$ and other critics of corporate governance have advanced a reform agenda that targets what they view as the central problem of executive compensation: managerial power over directors. ${ }^{332}$ They contend that the solution is, not surprisingly, less managerial power. ${ }^{333}$ They hope to achieve this end through a series of remedies, the highlights of which include improving transparency and disclosure to shareholders, requiring shareholder approval of certain types of executive compensation plans, and, most famously and controversially, permitting large shareholders access to the corporate proxy ballot to nominate a competing slate of directors. ${ }^{334}$

While BF's plan has been criticized on a number of grounds, the underlying rationale appears to me to be essentially sound. ${ }^{335}$ If the problem with executive compensation is managerial power over directors, boosting shareholder power seems the best alternative. Reducing managerial power may not help very much, however, if the central problem lies in boards' group dynamics. The diagnosis provided by Group Dynamics Theory requires a very different cure than that called for by Managerial Power's analysis. Under Group Dynamics Theory, the solution lies not in strengthening the link between directors and shareholders but in redesigning boards' decision-making processes.

\footnotetext{
${ }^{332} \mathrm{Id}$. at 189-216 (discussing possible remedies such as improving transparency, requiring shareholder approval and requiring corporations to place an alternative slate of board nominees on the corporation's proxy form under some circumstances). See also, e.g., Barris, supra note 2, at 99-100 (advocating greater involvement by both institutional shareholders and the courts ); John C. Coffee, Jr., Liquidity Versus Control: The Institutional Investor as Corporate Monitor, 91 COLUM. L. REV. 1277, 1336-66 (1991) (outlining the regulatory changes necessary to encourage institutional investors to monitor management); Elson, supra note 66, at 981-87 (advocating greater stock ownership by directors and longer director terms); Detlev Vagts, Challenges to Executive Compensation: For the Markets or the Courts?, 8 J. CORP. L. 231, 275-76 (1983) (proposing more independent compensation committees, shareholder approval of compensation plans, and great court scrutiny).

${ }^{333}$ See supra note 332.

${ }^{334}$ See Bebchuk \& Fried, supra note 2, at 189-216.

${ }^{335}$ See, e.g., Stephen M. Bainbridge, Director Primacy and Shareholder Disempowerment, 119 HARV. L. REV. 1735 (2006) (arguing that the current regime of limited shareholder voting rights is efficient and should be preserved); Leo E. Strine, Jr., Toward a True Corporate Republic: A Traditionalist Response to Bebchuk's Solution for Improving Corporate America, 119 HARV. L. REV. 1759, 1769-76 (2006) (portraying the traditionalist perspective as opposing greater shareholder power because, inter alia, it would weaken managers' ability to take risks).
} 
It may bear repeating at this point that I am not attempting to displace BF's reform proposals, but to supplement them. The problems associated with public company executive compensation likely stem from more than one source, and must be attacked accordingly. Reducing managerial power and improving boards' group dynamics should prove compatible goals.

Researchers have investigated several different methods of improving group decision-making, particularly for groups subject to groupthink. Less attention has been devoted to methods of breaking social cascades, perhaps in part because, as discussed above, most social cascades are fragile and easily disrupted by the introduction of new information. ${ }^{336}$ In this short space, I do not intend to advocate for one particular method or to advance a detailed blueprint for reform. Instead, my goal is only to illustrate the type of solution that might prove effective.

\section{A. Countering Groupthink}

The key to combating groupthink is to introduce reasoned dissent into the discussion. ${ }^{337}$ Once alternatives are proposed and seriously considered, the consensus that drives groupthink is much harder to maintain. Dissent can be generated either through the decision-making process or through the selection of the decision-makers. I will discuss each of these approaches below.

\section{Dissent Through Process}

There are four processes that studies have demonstrated produce superior decisions to fully interacting groups. The first process-driven method of creating conflict is Dialectical Inquiry. ${ }^{338}$ With this technique,

\footnotetext{
${ }^{336}$ See supra notes $119-120$ and associated text.

${ }^{337}$ See Robert S. Dooley \& Gerald E. Fryxell, Attaining Decision Quality and Commitment from Dissent: The Moderating Effects of Loyalty and Competence in Strategic Decision-Making Terms, 42 ACAD. MANAGT. J. 389, 389 (1999) (dissent can neutralize groupthink); Sonnenfeld, supra note 71, at 111 (best performing boards have contentious discussions); David M. Schweiger, et al., Experiential Effects of Dialectical Inquiry, Devil's Advocacy, and Consensus Approaches to Strategic Decision Making, 32 ACAD. MANAGT. J. 745, 745-46 (1989) (building dissent into group process may resolve groupthink problems).

${ }^{338}$ See Schweiger, supra note 337, at 747 (describing Dialectical Inquiry).
} 
the group is subdivided into two. ${ }^{339}$ The first group, tasked with synthesis, creates a proposal and provides it to the second group along with all supporting assumptions, arguments and information. ${ }^{340}$ The second group, tasked with antithesis, develops a counterproposal, based on different - though still plausible - assumptions. ${ }^{341}$ The two groups then meet and debate their separate recommendations until they reach agreement on the underlying assumptions and on a proposal based on those assumptions. ${ }^{342}$

Devil's Advocate is a second process that can introduce conflict. ${ }^{343}$ This technique involves dividing the decision-making group in two. ${ }^{344}$ One of these smaller groups examines the question at hand and develops a proposal. ${ }^{345}$ This proposing group relates the proposal, along with all supporting facts and assumptions, to the second, critiquing group. ${ }^{346}$ The critiquing group then attempts to find problems with both the proposal and the supporting facts and assumptions. ${ }^{347}$ The proposing group responds with a new proposal, along with new supporting assumptions (and possibly new facts), that attempts to address the issues identified by the critiquing group. ${ }^{348}$ This process continues until both groups are satisfied with the resulting proposal, and the supporting assumptions. $^{349}$

A third method is the Nominal Group Technique ("NGT"). ${ }^{350}$ NGT creates an unconventional and highly structured meeting. ${ }^{351}$ The group's members remain silent at the start of the meeting. ${ }^{352}$ A group facilitator presents the problem, and each group member then writes

\footnotetext{
${ }^{339} I d$.

${ }^{340} I d$.

${ }^{341} I d$.

${ }^{342} I d$.

${ }^{343} \mathrm{Id}$.

${ }^{344} I d$.

${ }^{345} I d$.

${ }^{346} I d$.

${ }^{347} I d$.

${ }^{348} I d$.

${ }^{349} \mathrm{Id}$.

${ }^{350}$ This technique was invented by Andre L. Delbecq and Andrew H. Van de Ven. See ANDre L. DelbecQ, ET AL., Group TeChNiques For Program Planning: A Guide TO NOMINAL GROUP AND DELPHI PROCESSES 7-8 (1975).

${ }^{351} I d$.

${ }^{352} I d$.
} 
down his or her ideas for solutions. ${ }^{353}$ After everyone has finished writing, the members take turns sharing one idea from their list with the group. ${ }^{354}$ The facilitator writes each idea down as it is stated on a whiteboard or screen projection so that the members can see all the suggestions. ${ }^{355}$ The group does not discuss any of the ideas until everyone has exhausted their individual lists of proposals. ${ }^{356}$ At that point, each idea is discussed in turn. ${ }^{357}$ Once all the ideas have been analyzed, each member rates or ranks the ideas privately, in writing. ${ }^{358}$ The solution that receives the highest rating or ranking from the group becomes the group's choice. ${ }^{359}$

The fourth and final formal decision-making method I will discuss here is the Delphi Technique. Unlike the other three methods, with the Delphi Technique the group's members do not interact with one another directly. ${ }^{360}$ Instead, they each provide written opinions, which are often anonymous. ${ }^{361}$ The group's leader or facilitator then responds to the reports by providing requested information, posing challenges from another member's analysis, or by reconstituting the question. ${ }^{362}$ The members then reconsider their views and write another written report. ${ }^{363}$ This process repeats for as many rounds as the group leader determines. ${ }^{364}$ Eventually, either the group reaches agreement through this process, or the leader makes a decision based on the group's input. ${ }^{365}$ These four methods attack groupthink in two different ways. Dialectical Inquiry and Devil's Advocate work by making dissent safe

\footnotetext{
${ }^{353} \mathrm{Id}$.

${ }^{354} \mathrm{Id}$

${ }^{355} \mathrm{Id}$.

${ }^{356} \mathrm{Id}$.

${ }^{357} \mathrm{Id}$.

${ }^{358} I d$.

${ }^{359} \mathrm{Id}$.

${ }^{360}$ See Delbecq, supra note 350 at 10-11; Stephen A. Stumpf, et al., Designing Groups for Judgmental Decisions, 4 ACAD. MANAGT. REV. 589, 592 (1979).

${ }_{361}$ See Delbecq, supra note 350 at 10-11; Stumpf, supra note 360, at 592; Cass R. Sunstein, Group Judgments: Statistical Means, Deliberation, and Information Markets, 80 N.Y.U.L.REV. 962, 1018-19 (2005).

${ }^{362}$ See supra note 361.

${ }^{363} \mathrm{Id}$.

${ }^{364} I d$.

${ }^{365} \mathrm{Id}$.
} 
through role-play. ${ }^{366}$ Dialectical Inquiry's antithesis group should feel free of the conformity pressures that cause groupthink because the members have taken on the role of dissenters tasked with creating an alternative proposal. Their success is measured not by being seen as correct (which too often may mean agreeing with the majority or with the group's leaders), but by advancing a reasonable alternative and defending it intelligently.

Devil's Advocate similarly creates a safe space for dissenting voices by assigning a sub-group the role of critiquing the proposal. Again, the "devils" are likely to feel comfortable pointing out flaws in the majority's plan because they have not just been invited but assigned to critique the proposal. ${ }^{367}$ The group's perception of their effectiveness will rise with the quality of their criticism.

The Nominal Group Technique and the Delphi Technique attack groupthink by requiring members to commit to positions before they know their colleagues' views. ${ }^{368}$ NGT requires group members to engage in private brainstorming and to reveal the product of that brainstorming before any discussion of the resulting ideas takes place. ${ }^{369}$ As a result, members cannot engage in self-censorship based on their colleagues' expressed views. Once their ideas and positions are public, it becomes psychologically more difficult for adherents of minority positions to recant and adopt the majority's view. In addition, NGT provides an opportunity for private voting after the discussion, to allow group members to express a dissenting view without fear of reputation consequences or reprisals. $^{370}$

The Delphi Technique achieves the same end by preventing the group members from ever interacting directly. ${ }^{371}$ Participants will learn their colleagues' views after exchanging the first round of reports, but here again, committing to their own positions in writing first should

\footnotetext{
${ }^{366}$ See Sunstein, supra note 361, at 1015-16 ("Those assuming the role of devil's advocate will not face the reputational pressure that comes from rejecting the dominant position within the group; they have been charged with doing precisely that. And because they are asked to take a contrary position, they are freed from the informational influences that can lead to self-silencing.").

${ }^{367} \mathrm{Id}$.

${ }^{368}$ See supra notes 350-359 and 360-365 and associated text (describing Nominal Group Technique and Delphi Technique, respectively).

${ }^{369}$ See supra notes 350-359 and associated text (describing Nominal Group Technique). ${ }^{370} I d$.

${ }^{371}$ See supra notes 360-365 and associated text (describing Delphi Technique).
} 
make them more resistant to conformity pressures. Keeping the process anonymous should help even more by protecting group members from reputation costs that may result from advancing unconventional or unpopular ideas. ${ }^{372}$

These techniques are not merely theoretically effective. Study after study has confirmed that groups using these methods make better decisions than the fully interactive groups that typify corporate boards' decision-making processes. ${ }^{373}$

\section{Dissent Through Group Composition}

Constructing diverse groups may offer an alternative method of combating groupthink. Janis argued that people with similar backgrounds and experiences - not to mention races, religions, and ethnicities - are more likely to form tightly cohesive groups. ${ }^{374}$ This idea has strong intuitive appeal. Individuals who have more in common seem more likely to form friendships and to care more about one another's good opinion. The result may well be a group culture that is reluctant to oppose any apparent consensus, for fear of appearing contentious, disruptive, or foolish. Ensuring that each group contains many people of diverse experiences should help protect against groupthink.

The empirical data on this point, however, is mixed. While some studies support the theory that diverse groups make better decisions, other research indicates that homogeneous groups function equally well. ${ }^{375}$ Diversifying corporate boards, if costless, should certainly be pursued. To the extent diversification is costly, however, it may be preferable to await more conclusive research.

\footnotetext{
${ }^{372}$ See Sunstein, supra note 361 , at 1018.

373 See supra note 337 (citing some examples).

${ }^{374}$ See Janis, supra note 15, at 250.

${ }^{375}$ Compare J.W. Dyson, et al., Group Composition, Leadership Orientation, and Decisional Outcomes, 7 SMALL GROUP BEHAVIOR 114 (1976) (homogeneity produces groupthink); L.R. Hoffman, Group Problem Solving in LEONARD BERKOWITZ, AdVANCES IN EXPERIMENTAL SOCIAL PSYCHOlogy, Vol. 2 99-132 (1965) (same); with Won-Woo Park, On Racial Diversity and Group Decision Making: Identifying Multiple Effects of Racial Composition on Jury Deliberations, 21 J. ORG. BEHAV. 873, 882 (2000) (homogeneity did not produce groupthink); Mark Schafer \& Scott Crichlow, Antecedents of Groupthink, 30 J. CONFLICT RESOLUTION 415 (1996) (same).
} 
An alternative method of bringing a type of diversity into the boardroom involves changing the boards' sources of information, rather than the characteristics of the board members themselves. We might adopt Carrie Menkel-Meadow's "Consensus Building Processes" to the corporate boardroom. ${ }^{376}$ Menkel-Meadow argues that Consensus Building Processes offer the possibility of "more creative and better substantive solutions to problems, where information is shared across disciplines and approaches from outside of the conventional frame are considered." 377 The essence of Consensus Building Processes is the inclusion of most or all affected groups in the discussion, and sometimes in the decision itself. ${ }^{378}$ Solutions developed through these processes may therefore be easier to implement, since most or all affected constituencies are consulted. ${ }^{379}$

As applied to the corporate context, Consensus Building Processes may involve introducing a more diverse range of views by inviting other corporate constituencies into the process. Representatives of major customers, suppliers, and affected communities might speak directly to the board to address their particular concerns regarding some major corporate decision. Employees might be represented by a union representative, to the extent the corporation is unionized and the union fairly represents the company's workers. Alternatively, the corporation might provide its employees with anonymous questionnaires administered by a neutral outside agency, to promote honesty and remove the fear of management retaliation.

Even if the board itself is homogeneous, Consensus Building Processes, far from reinforcing consensus in this context, might deconstruct the reflexive agreement characteristic of groupthink by undermining previously accepted assumptions. Consensus Building Processes have been used successfully to resolve a variety of decisionmaking contexts, including water use disputes, environmental clean-up conflicts, NIMBY ("Not In My Back Yard") issues such as airport siting, strategic planning, and international peace efforts, among many

\footnotetext{
${ }^{376}$ I am indebted to Carrie Menkel-Meadow for this possibility. For a more detailed explanation of Consensus Building Processes, including its origins in the work of Jürgen Habermas, see Carrie Menkel-Meadow, The Lawyer's Role(s) in Deliberative Democracy, 5 NEV. L.J. 347, 354-366 (2004-2005).

${ }^{377} I d$. at 360 .

${ }^{378} I d$. at 361

${ }^{379} I d$. at 360.
} 
others. ${ }^{380}$ I am unaware, however, of any scientific study measuring the efficacy of Consensus Building Processes in alleviating groupthink. Nevertheless, Consensus Building Processes appear to possess great potential and are well worth studying further.

\section{B. Dissolving Social Cascades}

Most social cascades are relatively easy to disrupt by providing new, credible information that indicates the cascades' selection is incorrect. ${ }^{381}$ Perhaps because cascades are generally considered to be fragile, researches have spent little time investigating methods of collapsing cascades that prove resilient. ${ }^{382}$ In contrast to most social cascades, executive compensation cascades are predicted to be relatively durable. Cascades collapse because new information comes to light that exposes the objective invalidity of the cascade's choice. In the case of our first year law student class, the cascade may break when the professor tells the class the correct answer. ${ }^{383}$

Executive compensation cascades are not similarly vulnerable to new information. The relevant question with executive compensation is whether corporations are paying their executives more than they are worth. Without a well-functioning market or some alternative objective measure of value, there appears little likelihood of any information appearing that would shift boards' perceptions of executives' value as a whole. This is not to say that a particular executive might not be devalued by new data. A board that learned the company's chief executive had embezzled company funds, for example, would certainly lower its estimation of the executive's worth. But this type of information will tell the broader market essentially nothing about the

\footnotetext{
${ }^{380} I d$. at $363-64$.

${ }^{381}$ See Bikhchandani, supra note 17, at 158 (discussing means of disrupting cascades).

${ }^{382} I d$. (arguing that cascades are fragile). But see Angela A. Hung \& Charles R. Plott, Information Cascades: Replication and an Extension to Majority Rule and ConformityRewarding Institutions, 91 AM. ECON. REV. 1508, 1517-18 (2001) (finding that majority rule counteracted social cascades so long as only the group's decision counted in determining rewards and there was no individual benefit for voting for the correct result). Because the relevant group for our purposes is the group of publicly traded corporations, majority rule is not a helpful device to aid in setting executive compensation.

${ }^{383}$ I acknowledge that there may never be a true objective answer to the question of whether a court case was decided correctly. It is enough for my purposes here that the first-year students will likely take the professor's response as objectively correct.
} 
value of leadership in general. The salary that an honest executive should command would remain largely a mystery, subject to a social cascade.

Other than introducing new information, the only apparent method of dissolving a social cascade is to isolate each board from the decisions made by other corporations. ${ }^{384}$ Directors who remained ignorant of the decisions of their peer companies could not be influenced by a perception that other corporations possessed more information about the value of corporate leadership. Isolation might therefore break the cascade caused by compensation consultants. ${ }^{385}$ Quarantined boards might peg compensation purely on the basis of internal factors, such as a percentage of the company's profits, or a multiple of the lowest paid worker's salary, rather than attempting to exceed the average amount paid by similar companies.

This approach may not prove feasible. Directors of public corporations are often chief executive officers themselves, so they will have at least their own pay to use as a benchmark. ${ }^{386}$ Moreover, directors tend to belong to the same social networks, and may therefore garner informal knowledge about compensation practices at other large corporations. $^{387}$ Worst yet, federal securities regulation requires extensive - if not complete or clear - disclosure of executive compensation. ${ }^{388}$ And even if that requirement were eliminated, the financial press would no doubt remain devoutly interested in what CEOs earn, and would work hard to discover and publish at least some version of the truth.

Even if the feasibility issues could somehow be dealt with, isolating the directors from this sort of information risks worsening the

\footnotetext{
${ }^{384}$ See Bikhchandani, supra note 17 , at 163 ("[I]t would be socially most advantageous if one could isolate different groups of decisionmakers, and then disclose their actions simultaneously.").

${ }^{385}$ See supra notes 112-118 and associated text (discussing the role played by compensation consultants).

${ }^{386}$ See supra note 327.

${ }^{387}$ While it is difficult to document the degree to which directors socialize together, some work has been done to measure the extent to which directors are linked simply by virtue of sitting on more than one board. See Gerald F. Davis et al., The Small World of the American Corporate Elite, 1982-2001, 1 STRATEGIC ORG. 301-26 (2003) (finding that in $1999,97.4 \%$ of all corporations in his sample group of 811 Fortune 1000 firms could be linked through overlapping directorships to Chase Manhattan in four steps or fewer).

${ }^{388}$ See 17 C.F.R. $\$ 229.402(2001)$.
} 
capture problems unveiled by Managerial Power theorists. ${ }^{389}$ A captured board might use its forced ignorance as an excuse for awarding excessive pay to its chief executive. Captured boards might defend excessive compensation by arguing that the pay seemed justified based on internal factors, and the directors were required to ignore external benchmarks that might otherwise have raised a red flag.

While barring disclosure of executive compensation may prove both infeasible and undesirable, excluding compensation consultants from the process may weaken the social cascade's power. Although directors are likely to have some information about peer companies' compensation practices, that sort of rumor-based knowledge will likely lack the impact of a comparison chart showing the company's CEO woefully below the average pay of "comparable" corporations. ${ }^{390}$ Perhaps consultant-deprived directors would perform a comprehensive analysis on their own using SEC filings, but this seems unlikely given the current ethos of public company directors. It feels counterintuitive to attempt to dissolve a social cascade by depriving individuals of information, but that may prove the best available option in the case of executive compensation.

\section{$\underline{\text { Conclusion }}$}

I have argued that Group Dynamics Theory provides an alternative or contributing explanation for the observed inefficiencies in public company executive compensation. The evidence for my claim comes largely from psychological studies of group dynamics. While the phenomena I have discussed are well-documented and appear to explain corporate practices well, they provide only indirect evidence of the problem's root cause. Theorists who study executive compensationregardless of which theory they believe -study board behavior indirectly, by examining the results of board decision-making. To my knowledge, there has been no research employing direct empirical observations of directors' behavior in and out of the boardroom.

Theorists can learn a great deal from studying the effects of boards' decision-making. But those effects are and will remain subject to varied interpretations unless and until we can observe boards directly. Directors may be understandably reluctant to be studied this way, and

\footnotetext{
${ }^{389}$ See supra Part I (describing the problems of captured boards).

${ }^{390}$ See Dorff, supra note 3, at 267; Yablon, supra note 108, at n.5.
} 
direct observations pose numerous practical difficulties. Some of these challenges including meeting the corporation's need for confidentiality while maintaining scientific openness; persuading directors that such studies are worthwhile; and avoiding the risk that the act of observation will change directors' behavior. Nevertheless, these obstacles must be overcome if we are ever to gain a sufficiently definite understanding of corporate governance dynamics to achieve effective regulatory reform. 